\title{
GHEORGHE POPILIAN AND THE ROMAN POTTERY FROM OLTENIA
}

\begin{abstract}
Gheorghe Popilian's monograph Ceramica romană din Oltenia is the main reference textbook for southern Romania, at least. The work is now pretty old - more than four decades - and although still very useful, it is obviously the product of its age. For instance, the information connected to fabrication, constantly retrieved in general commentaries or in catalogue's descriptions, is rather sketchy ('fine' or 'coarse'). More than that, the relationship between the classes and types of pots and the fabrication classes - including the colour - is not always crystal clear, without a thorough analysis.

This study is not a review; it is rather an attempt to turn the book in a handy database. The enterprise is not targeting the whole collection of artefacts, but those suspected to be mainly the result of the local production, as an expression of the local taste and demand, as jars, beakers, flagons, cups, censors, bowls, dishes, lids. I paid a special attention to the types made of many items, because in these cases the presumption of the local manufacture is stronger.

Criteria used by Popilian in drawing his typology are not even, therefore the analysis has to perform along all possible benchmarks: general morphology, terminations (rims, bases, handles), fabrication, colour, decoration, size, when not even ethnographic references. Such details could prove useful when handle fragmentary pottery.

A certain limitation comes from the way in which the collection of study was provided, as the overwhelming majority of the pots were discovered in cemeteries. The distribution of the main types of recipients could prove quite different in civilian settlements or military garrisons.
\end{abstract}

Keywords: Roman Oltenia, pottery, fabrication, colour, statistics

\section{INTRODUCTION}

$\mathbf{T}$

he present study, dedicated to the Roman pottery from Oltenia as rendered in a well-known monograph, ${ }^{1}$ is not just a theoretical endeavour. In the last years I found myself several times in troublesome situations, trying to make a distinction between the Roman pottery and the so-called Chilia-Militari pottery, working on archaeological sites from the area of Limes Transalutanus. ${ }^{2}$ I concluded then that there is no simple scientific way to make a difference, archaeologists having to rely mostly in their experience, which is not the right way to do things.

I have decided thus to turn the old book in a database, in order to use it easily and clearly, especially for the foreign reader and the younger generations, less accustomed with the typical traits of the Romanian archaeology in the 1970s. I should immediately add: and for myself. In order

1 POPILIAN 1976.

2 TEODOR/BĂDESCU/HAITĂ 2015 (Alexandria); TEODOR/ȘTEFAN/BĂDESCU 2017 (Săpata de Jos); TEODOR 2016 (Băneasa).

\section{Eugen S. Teodor}

Romanian National History Museum, Bucharest esteo60@yahoo.co.uk

DOI: $10.14795 /$ j.v6i3.407

ISSN $2360-266 \mathrm{X}$

ISSN-L 2360 - 266X 
to do so, I had to 'normalize' the available information, meaning to cut the unnecessary variations, always involved in a discursive text, including the catalogue descriptions. As any normalization means also an alteration of the original, I had to make sometimes difficult choices.

Although the imports are very expressive for the economic status of a Roman province, my diggings ${ }^{3}$ drove my attention mainly towards the all-day pottery, casually encountered in any remote site of the province. The way in which a specific community turns the 'Roman culture' in a specific set of objects, defining their needs, their economic strength, and finally their identity, is motivating me more than arguments coming from the 'prestige' game. Therefore, I will deal here only with pottery of very likely local (or regional) production.

I will start with geographical and historical issues, in order to make clear the relationship between modern day Oltenia and Dacia Inferior, pursuing with a more developed section about the aims of this study. A long digression about colours in pottery descriptions will be helpful understanding what 'normalisation' is, which could be a small study by itself. Another section is dedicated to fabrication problems, more exactly about the way in which Gheorghe Popilian managed it.

The middle section of the paper is dealing with methodology, clarifying facts about how the content from the catalogue was converted in a database and the way in which the Annexes of the paper should be used. The closing part of the study is concerning the statistical outcome, being commentaries about data displayed in the Annexes, as, for instance, the frequency of certain types, their fabric or colour.

The main text is doubled by eight annexes containing statistics, supposed to sustain the main text. I will add a supplementary file (as Excel or Pdf file, at editor's choice), containing raw data, transcribed and formalised from the catalogue of the monograph, adding missing dimensions, from scaled images.

I am really grateful to the JAHA editor for housing here an unusual large paper, thus not being forced to make it public as grey literature, as I am close to use reference data from Popilian's book in a subsequent paper about the Roman pottery harvested in diggings at the Roman fort from Băneasa (Teleorman County), located east of Olt River, outside Oltenia.

\section{GEOGRAPHICAL ISSUES}

The Roman conquest ended with the Dacian kingdom dismantling, in $106 \mathrm{AD}$. The military actions took place across wide territories, far outside the land later occupied by the Roman province(s). The most likely explanation is that the defeated Dacians have continued to oppose resistance, even beyond the limits of the kingdom led by Decebalus, and the Romans stopped only when the resistance was completely smashed. In the day after, a new Roman province was set up, stretching on upper Banat - the main military corridor to Dacian land - and most of Transylvania, the name of

\footnotetext{
3 As the Roman fort from Răcari (Dolj County, 2003-2010) or the Roman fort at Băneasa (Teleorman County, 2016-2018), both providing artefacts especially from the first half of the third century (Băneasa exclusively).
}

the medieval country located inside the mountains. All the territories located outside the Carpathian Mountains, as Oltenia ${ }^{4}$, Muntenia ${ }^{5}$ and southern Moldavia, ${ }^{6}$ but also a strip of land in southern Transylvania, joined firstly the older province Moesia Inferior. This set-up lasted only until the death of the conqueror Trajan. His successor, Hadrian, had to face a strong uprising made mainly by Sarmatian tribes, located both west and east of Dacia. On brief, he saved the new province of Dacia, but with a price: the Roman army was withdrawn from large territories, as southern Moldavia and all Muntenia, left for Sarmatian herding. Interesting to note, those territories were not part of the former Dacian kingdom, although inhabited by related populations (more likely Getai than Dacians), therefore not Roman land by the law of war. What remained was reshaped in two distinct provinces: Dacia Superior for Banat and centre of Transylvania, and Dacia Inferior for Oltenia and south-eastern Transylvania. Very shortly after, Dacia Superior was split, territories north of the middle course of Mureş River becoming Dacia Porolissensis. ${ }^{7}$

The configuration of Dacia Inferior, comprising (mostly eastern) Oltenia, southern and south-eastern Transylvania, could look awkward today, but it was strongly motivated by two sets of facts: one was the area occupied by troops coming mainly from Moesia Inferior; the second was the possibility to set the outer border along a main river, Olt (which is giving also the name of the medieval Oltenia), on all its lower and middle course. The connection between the two parts of Dacia Inferior - located south and north of Meridional Carpathians - was difficult, narrow, and pretty much unique, at least in the mid second century: the Olt river gorge, a wild, long, mountainous and forested valley. The two parts of that province are different under many aspects, like climate (harsh and cold in north, milder but also drier in south), and as distribution of the civilian population. Oltenia has the only known Roman town, which is also the capital, Romula, ${ }^{8}$ and the only which has a dens rural population, including villae rusticae. $^{9}$

Sometimes at the threshold of the second and third century, the Roman border from Olt River was pushed forward, between 20 and $50 \mathrm{~km}$, the new frontier - Limes Transalutanus - being a shortcut between the Olt River mouth and the south-eastern corner of Transylvania, opening another crossing point over Carpathians, the Bran Pass, at over $1200 \mathrm{~m}$ altitude. The new territory, from western Muntenia, was under the Roman control something less than half a century (until 245 AD), keeping a rural character, not very well studied. ${ }^{10}$

North of Danube lays Romanian Plain, stretching for about $120 \mathrm{~km}$, up to the hills. This plain was devoid of people

\footnotetext{
The name of the medieval province located west of the lower Olt River, between Danube and Southern Carpathians, known also as Small Walachia.

The name of the medieval province located east of the lower Olt River, between Danube and Southern Carpathians, known also as (Great) Walachia.

6 Moldavia is the medieval Romanian state located east of the Oriental Carpathians.

In 168 AD Dacia Superior took the name of Dacia Apulensis, and Dacia Inferior became Dacia Malvensis, having in existence also Dacia Porolissensis, north of Mureș River (PETOLESCU 2010, 168-169).

${ }^{8}$ Uncertain is the urban status of Sucidava; unclear also if Malva and Romula are the same thing (PETOLESCU 2018, 60)

9 TUDOR 1978, 218-238.

10 TEODOR/ŞTEFAN 2014, 32-34.
} 
for at least half a century, previous to the Roman conquest. ${ }^{11}$ At a relatively short time after the army was withdrawn west of Olt River, the Romanian Plain suddenly came to life again. The population does not seem new, having obvious Dacian roots, and it probably has descended from the hills, still forested today and superficially archaeologically known. Around $150 \mathrm{AD}$ a new material culture was born, known as Chilia-Militari. ${ }^{12}$ It is a rural civilization, housing in huts more or less buried, with an inventory strongly influenced by Romans, from pottery to weapons or outfit. Comparing this with the emptiness from the first century $\mathrm{AD}$, we can easily guess that they were allowed to stay there; apparently they were Roman amici, creating a buffer between Dacia Inferior and the Sarmatian herd breeders, located about $200 \mathrm{~km}$ eastward. When the Romans came back, in western Muntenia, in the early third century, the villages type ChiliaMilitari apparently have continued undisturbed their live. Only that, this time, some of them were located inside the new frontier, and the others - outside. In other words, some of the villagers became Roman citizens, but the others - not; their life apparently did not change a lot, and we are facing an interesting experience: an archaeological culture stretching on the both sides of a frontier. There are claims that also, in 245 AD, when the Roman defence along Limes Transalutanus was crushed by Carpi, the villages of Chilia-Militari culture were not disturbed, for at least another half a century. ${ }^{13}$

This relatively lengthy description was needed in order to understand both the trigger of this study, and some of the facts at the stake. The main question bothering me from several years is if Chilia-Miliari culture is a 'barbarian' culture with strong Roman influences, or the other way around - a Roman culture with deep local roots. In order to fix this, one needs a clear comparison term about the pottery from Oltenia.

\section{AIMS}

Over four decades ago Gheorghe Popilian published his $\mathrm{PhD}$ dissertation, Ceramica romană din Oltenia (Roman Pottery from Oltenia, 1976). That was the first monograph dedicated to Roman pottery from an entire (modern) province of Romania, and still is. ${ }^{14}$ The work is famous and cited in many books concerning pottery, being the main reference for southern Romania. I used it also, in many instances, including in the last years for two different papers. With that occasions came up that it is useful, but not easy to handle. When the researcher is a foreigner, it cannot be than worse. This is not mainly about understanding Romanian language, relatively easy to ketch for Latin or Slavic speaking archaeologists; it is more about knowing Romanian archaeology and some of its common places, concepts and habits.

The monograph was made by three major parts: a first one, which contains general commentaries for all the

\footnotetext{
11 Due to retaliation actions taken by Romans, several times along the first century AD (TEODOR 2015, 3-4; TEODOR 2018, 444 with the Table 3, 452).

12 TEODOR/BĂDESCU/HAITĂ 2015, 90-93, for a general presentation and literature.

13 BICHIR 1984, esp. 86-94 (chronology), 95-112 (conclusions), 107-112 (French abstract).

14 See yet RUSU-BOLINDET, 2007, which is a monograph for the pottery from the antique town Napoca, in northern Dacia (Porolissensis).
}

classes and types of pottery (pages 23-138), ${ }^{15}$ the second is a catalogue (p. 157-221) and the last is made of the plates (83 of them, after the page 246). The whole thing is split in imported pottery (terra sigillata, amphorae, mortaria, others) and (more or less) local pottery. Inside the last category, one will find first luxury pottery, as local imitations of terra sigillata, pottery with applications, stamped pottery and painted pottery, followed by all day use pottery. A final part has dealt with Dacian style pottery of the Roman age.

The common use pottery makes the largest part of the book, giving also the major part of the catalogue (nos. 315-959), and will be the object of concern in this paper. Our basic interest is to enable us to deal with it, to understand exactly what 'Roman' means in this corner of the world, and to get solid comparison terms for studies in the areas where the Roman contribution is more diluted, as would be Chilia-Militari culture, or the garrisons located east of the Olt River. No doubt, a good overview will provide data for comparative studies in wider areas, as the northern Balkans.

The perspective will be a statistic one, trying to gain knowledge about the most characteristic ceramic products, which are fairly supposed to be local manufacture. Needless to say, maybe, in 1970 s there were no provenance studies, and they are still missing. Such a presumption - the more numerous they are, safely local would be - is still the only one operating. Therefore, I shall focus on well documented shapes, ignoring casual occurrences.

\section{COLOURS}

Gheorghe Popilian was taking his notes in late 1960s and early 1970s. Of course, he did not use any advanced means for colour identification, handling the colours' names in a naturally way, as they come from the all day language. More than that, he did it in Romanian, forcing us not only to translate them, but also to explain them and 'normalise' the use, avoiding unnecessary variation. Being an all-day language, and not a controlled list, there were used synonyms which could divert statistics. For instance, he used both the traditional 'cenuşiu' ('the colour of the ash') and the neologism 'gri' (from French 'gris', i.e. grey); but this is the simple case. There are many shades of red in pottery, as well as in language. It seems he took some shade-names depending on inspiration. For instance, in the commentaries for the one handle flagons he was writing that they are generally brick-red ('roşu-cărămiziu') ${ }^{16}$. Looking at the catalogue, one can see that the archaeologist used in fact the next terms: red, brick-red (majority), brick-like ('cărămiziu'), when not even light brick-like ('cărămiziu deschis'). ${ }^{17}$ Speaking about the slip (named 'paint', Rom. 'vopsea'), it is never 'brick-red', but red (most of the time), also dark-red or brown-red. Such differences cannot be taken at their face value, because it is impossible that the most frequent shade of the pot not to occur once on coating (the basic materials were the same). This 'anomaly' can be relatively easy explained by a sort of 'speaker-sensitivity': a smooth coat cannot be 'brick-like',

\footnotetext{
${ }^{15}$ I am following here RAYNER 1994, 5, for which forms are 'classes of vessels sharing form and function' (as flagon, jar, bowl, etc.), while 'type' means a sub-class depending on a certain feature, like colour, fabrication, size or morphology (like 'grey', 'coarse', 'small', 'double-handled', etc.).

16 POPILIAN 1976, 96.

17 POPILIAN 1976, 185-193.
} 
due to the roughness suggested by the main word, 'brick'. As an overall use, 'brick-red' is a shade darker than red. As we shall see, there are too many 'red' notions into the speech to be all accepted.

This kind of problems made me to change some of the mentioned shades in the database; this is the case, for instance, with 'black'. There is no 'pure black', which is a convention; it cannot be present on pottery, no matter how fine it is. In several situations Popilian wrote that the grey-ware could have a 'black' coat, or at least it would be an imitation of terra nigra. Or, because it cannot be 'black', it is obviously a darker grey. Such changes, yet, affect only a small part of the shades used in description (probably under 5\%).

The next question is what shades could be accepted and which had to be rejected? We need an objective colour scheme, based on physical properties. RGB could offer the logical scheme. Its name is the acronym of the three primary colours - Red, Green and Blue. All other colours and shades can be obtained mixing the primary colours. The intensity of each primary element is set on a scale with 256 steps, 255 being 'maximum' and 0 being 'null'. ${ }^{18}$ The equality of the three always produces neutral shades; for instance $0,0,0$ is pure black, $255,255,255$ is pure white, and $127,127,127$ gives a middle grey. Mixing two primary colours creates the other three main colours: yellow $(255,255,0)$, cyan $(0,255,255)$ and purple $(255,0,255)$, as one could see on any image editor on its own computer (Fig. 1).

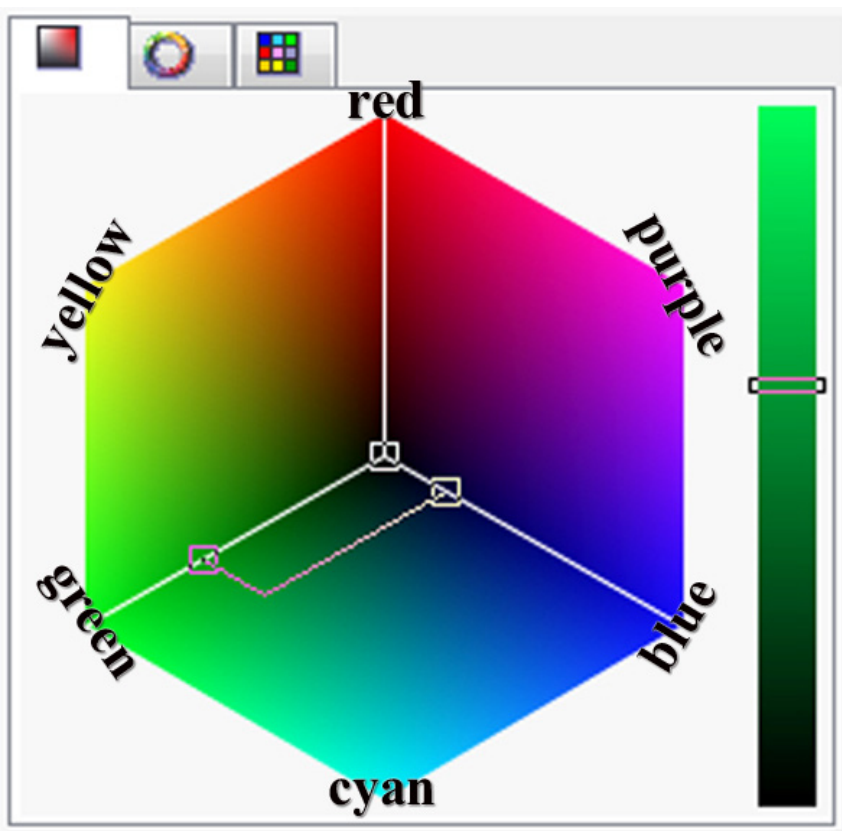

Fig. 1. The primary colours (RGB) and the main colours produced by mixing two of them. Window 'Edit fill' in CorelDraw, annotated with the colour names.

Using half-tones for one of two primary colours creates a new set of basic colours, as orange (between red and yellow), yellow-green, lime green (between green and cyan), sky-blue (between cyan and blue), blue-purple, and (intense) pink (between purple and red), as it is rendered in Table 1 . On the right side of the same table one could get

\footnotetext{
${ }_{18}$ Sometimes they can be expressed as percent, but we will use the full scale.
}

shades of yellow (up) and red (the rest, without the last), all theoretically of direct interest for pottery description. Working with a book in which the shades are named, but not defined, our question is how many clearly different shades could be named on the red part of the spectrum, or, simpler, where the primary red filter is dominant. In my count, they should be 12, adding two 'pure' colours from the left part of the table, red and orange. Of course, pure colours are not expected in the real world, and still less on artefacts of two millennia old; similar shades could occur, but dimed. ${ }^{19}$

About neutral colours the descriptive texts written by Popilian are not making problems. We could have something 'whitish', but only when comes to kaolin made artefacts. In a few instances some coats are 'black', all transformed in statistics as 'dark-grey', and same as the few other instances when he was writing 'cenuşiu închis' (dark-grey). In a great majority the pots fired reductive are labelled as 'grey', covering probably a large span of shades, including some dark yellow-greys, red-greys, possibly some purple- or bluegreys.

When comes to oxidised pottery, there is an overwhelming diversity of shades, and not always for a good reason. The best test is about the 'brick-like' colour (Rom. cărămiziu). The word is frequently used not only by Gheorghe Popilian, but by many Romanian archaeologists. Although never explained, it seems to be darker than 'red', in the sequence roşu (red), roşu-cărămiziu (brick-red), cărămiziu (brick-like), all of them being abundant in literature. The Romanian dictionaries are not helpful, saying only that 'cărămiziu' is an adjective, being something reddish as a brick... I then made a test, both on an archaeological Facebook group, and on broader Internet. The Facebook test consisted in displaying a set of 12 shades with a Red major term (in RGB), asking for names. I got only four answers of 'cărămiziu' (brick-like), all of them darker than a 'red', and all coming from... trained archaeologists. ${ }^{20}$

Surprisingly, Popilian has used not only red, brickred and brick-like (Rom. cărămiziu), but also 'light brick-like' (Rom. cărămiziu deschis), a shade outside the logic scheme. If the sequence red - brick-red - brick-like in one from intense red to a darker shade, 'light brick-like' does not make sense, and will be translated just as 'red'.

A short Internet inquiry has brought the results from the Table 2. The international experience - or, at least, the English speakers' experience - is the same as the Romanian speaker intuition, naming 'brick-red' a shade darker than 'red', although the diversity of those shades (from Table 2) is disheartening. ${ }^{21}$ A good thing is that a well-known dictionary, as Meriam-Webster, is providing a useful, though short definition, as 'reddish-brown', similar to 'brick-red' from the Table 1 , being thus darker than 'red' ( $76 \%$ in greyscale, compared to 58\%).

Such tests were necessary before giving a table of translations regarding pottery shades, as available in Table 3. I used only shades made of quarters (or multiples) of the primary RGB colours (having the limits at 255, 191, 127, 64,

19 As, for instance, a red with RGB 230,5,5, or an orange 230,115,5.

${ }^{20}$ Most of the subjects of the test were fans of archaeology with no professional training.

${ }^{21}$ The brick-red issue caught also attention of GERHARZ/LANTERMAN/ SPENNEMANN 1988, 88. 
Table 1. Basic RGB colours and some of their main shades

\begin{tabular}{|c|c|c|c|c|c|c|c|c|c|}
\hline main & $\mathbf{R}$ & G & B & hexa & derived & $\mathbf{R}$ & G & B & hexa \\
\hline white & 255 & 255 & 255 & \#FFFFFF & (grey, yellow and red) & & & & \\
\hline black & 0 & 0 & 0 & $\# 000000$ & yellowish grey & 191 & 191 & 127 & \#BFBF7F \\
\hline mid grey & 127 & 127 & 127 & $\# 7 F 7 F 7 F$ & greyish yellow & 191 & 191 & 64 & \#FFFF7F \\
\hline dark grey & 64 & 64 & 64 & $\# 404040$ & pale yellow & 255 & 255 & 64 & \#FFFF40 \\
\hline light grey & 191 & 191 & 191 & \#BFBFBF & reddish grey & 191 & 127 & 127 & \#BF7F7F \\
\hline red & 255 & 0 & 0 & \#FF0000 & yellowish-red & 255 & 127 & 64 & \#FF7F40 \\
\hline orange & 255 & 127 & 0 & \#FF7F00 & orange-red & 255 & 64 & 0 & \#FF4000 \\
\hline yellow & 255 & 255 & 0 & \#FFFF00 & very light red & 255 & 127 & 127 & \#FF7F7F \\
\hline yel.-green & 127 & 255 & 0 & \#7FFF00 & light-red & 255 & 64 & 64 & \#FF4040 \\
\hline (light) green & 0 & 255 & 0 & \#00FF00 & light pink & 255 & 64 & 127 & \#FF407F \\
\hline lime green & 0 & 255 & 127 & \#00FF7F & moderate red & 191 & 64 & 64 & \#BF4040 \\
\hline cyan* & 0 & 255 & 255 & $\# 00$ FFFF & brick-red & 191 & 0 & 0 & \#BF0000 \\
\hline blue & 0 & 127 & 255 & $\# 007 F F F$ & dark red & 127 & 0 & 0 & \#7F0000 \\
\hline dark blue & 0 & 0 & 255 & $\# 0000 \mathrm{FF}$ & light brown & 191 & 127 & 0 & \#BF7F00 \\
\hline blue-purp & 127 & 0 & 255 & \#7F00FF & brown & 127 & 64 & 0 & \#7F4000 \\
\hline purple & 255 & 0 & 255 & \#FF00FF & dark brown & 64 & 0 & 0 & $\# 400000$ \\
\hline pink & 255 & 0 & 127 & \#FF007F & olive & 127 & 127 & 0 & \#7F7F00 \\
\hline
\end{tabular}

Table 2. Shades for 'brick-red' definition

\begin{tabular}{cccll}
\hline shade & grey equiv. ${ }^{22}$ & hexa code & source & definition \\
\hline $58 \%$ & $\# f f 0000$ & RGB (computer) & red (comparison) \\
\hline $72 \%$ & $\# B 22222$ & ColorHexa & fire brick \\
\hline $65 \%$ & $\# C C 3300$ & CorelDraw appl. & brick-red \\
\hline $80 \%$ & $\# 841 F 27$ & Colorcombos & old brick red \\
\hline $67 \%$ & \#c62d42 & Crayola & brick red \\
\hline $77 \%$ & $\# 7 a 3 c 32$ & Benjaminmoore & brick red \\
\hline $70 \%$ & \#b6291c & Brambleberry & brick red oxide pigment \\
\hline & & Meriam-Webster & 'a moderate reddish brown' \\
\hline
\end{tabular}

As I said, fully saturated colours do not exist in the real world of the archaeological repositories. It is more likely to find them desaturated, as in the Figure 2, most of the time on the gap between $20 \%$ and $40 \%$. The main thing here is that, no matter of saturation, one can safely perceive as different 5 shades lighter than the pure red and five shades darker than the pure red. This is what I did in the Table

0 ), as in the right side of the Table 1 , but re-arranged.

The shades from the Table 3 are theoretical, as they are completely saturated. A pure red, for instance, does not exist in nature. ${ }^{23}$ The aim was not to count the number of shades, but to see approximately how many shades are in the red spectrum, using limited means (as quarters of the RGB primary colours), and hopefully distinguishable by most of the people. The real problem is not if they can see them as different shades, but the way in which they are expressing one and the same shade with the same world. ${ }^{24}$ For instance, 'brown' can be expressed, in Romanian, as maro (reddishbrown, from French marron), brun (brown, also of French origin? $)^{25}$, cafeniu (as grinded coffee), castaniu (as chestnut fruit), and all of them could be found in literature. Such a variation, although linguistically normal, is statistically disturbing, and asks for normalisation.

${ }_{22}$ The black percentage after converting the colours to greyscale.

${ }^{23}$ Note that Munsell system does not contain fully saturated colours.

${ }^{24}$ The experiment done in Facebook was a complete disaster!

25 As presented in dictionaries (DEX 2009; Dicționar de neologisme, 1986), although two colour names which are almost perfect synonyms, borrowed from the same language, is something hard to believe.
3 , keeping in use 11 shades with a dominant red primary colour, and redirecting 3 Romanian expressions (roșu-închis, roșu-brun and cărămiziu-deschis) to other shades of the scale; those three expressions (with low occurrence) are suspected to represent the unnecessary linguistic variation.

I have also done other changes in order to come closer to the archaeological needs. For instance, the pure pink (\#FF007F) from the Table 1 was further neglected, as an 'impossible colour', being chosen instead a lighter pink (\#FF407F), as the main pink shade of archaeological use, introducing further a still lighter pink (\#FF7F7F). Similarly, I did not use pure orange (\#FF7F00) or pure yellow (\#FFFF00, see Table 1), but the orange-red (\#FF4000) and pale yellow (\#FFFF40) instead (see Table 3).

I have chosen English names following both the archaeological literature practice and the expert advice from the Munsell Solil Color Chart, avoiding any unneeded poetical licences, ${ }^{26}$ using only clear-cut names (grey, yellow,

${ }^{26}$ As the examples given by Munsell Chart: rusty brown, mouse gray, lemon yellow. 
Table 3. Translations of the colour shades used in pottery description

\begin{tabular}{|c|c|c|c|c|c|c|}
\hline Romanian name & abrR & English name & abrE & Munsell 27 & hexa & shade \\
\hline cenușiu deschis & $\mathrm{CA}$ & light grey & liG & $\mathrm{N} 7 / 0$ & \#BFBFBF & black $25 \%$ \\
\hline cenușiu mediu & $\mathrm{CM}$ & middle grey & $\mathrm{mG}$ & N $5 / 0$ & $\# 7 F 7 F 7 F$ & black $50 \%$ \\
\hline cenușiu închis & $\mathrm{CZ}$ & dark grey & dG & N $3 / 0$ & $\# 404040$ & black 75\% \\
\hline cenușiu-gălbui & CG & yellowish grey & yG & $10 Y 7 / 4$ & \#BFBF7F & \\
\hline albicios & A & white(ish) & W & $\mathrm{N} 8 / 0$ & \#Е0EOEO & black $<10 \%$ \\
\hline gălbui-cenușiu & $\mathrm{GC}$ & greyish yellow & gY & $10 \mathrm{Y} 6 / 8$ & \#FFFF7F & \\
\hline $\mathrm{roz}$ & $\mathrm{RZ}$ & (light) pink & $\mathrm{P}$ & $2.5 \mathrm{R} 5 / 16$ & \#FF407F & \\
\hline (roșu deschis) & & light pink & lip & $2.5 \mathrm{R} 6 / 12$ & \#FF7F7F & \\
\hline roşu deschis & $\mathrm{RD}$ & light red & liR & $7.5 \mathrm{R} 5 / 16$ & \#FF4040 & \\
\hline roșu-gălbui & RG & yellowish red & $y R$ & $10 \mathrm{R} 6 / 12$ & \#FF7F40 & \\
\hline roșu-portocaliu & $\mathrm{RP}$ & orange red & oR & $10 \mathrm{R} 6 / 16$ & \#FF4000 & \\
\hline roșu & $\mathrm{RR}$ & red & $\mathrm{R}$ & - & \#FF0000 & \\
\hline roșu cărămiziu & $\mathrm{RC}$ & brick-red & $\mathrm{bR}$ & $\sim 10 \mathrm{R} 2 / 8$ & \#BF0000 & \\
\hline cărămiziu & $\mathrm{RM}$ & ('brick like') dark red & $\mathrm{dR}$ & $\sim 10 \mathrm{R} 1 / 4$ & $\# 7 F 0000$ & \\
\hline (roşu-închis) & & (dark red - see dark red) & & & & \\
\hline (roşu-brun) & & (brown red - see dark red) & & & & \\
\hline (cărămiziu-deschis) & & (light brick-red - see red) & & & & \\
\hline brun-cafeniu (deschis) & $\mathrm{BA}$ & light brown & liB & 7.5YR 5/10 & \#BF7F00 & \\
\hline brun-castaniu (mediu) & $\mathrm{BB}$ & middle brown & $\mathrm{mB}$ & 5YR $2 / 6$ & $\# 7 F 4000$ & \\
\hline brun (închis) & $\mathrm{BZ}$ & dark brown & $\mathrm{dB}$ & 7.5YR $1 / 2$ & $\# 400000$ & \\
\hline necunoscut & $x$ & missing information & $x$ & & & \\
\hline cu angobă & ${ }^{*} \&$ & slip (having colour...) & *\& & & & \\
\hline cu glazură & $* / 0$ & olive glaze & $* / \mathrm{Ol}$ & $5 G Y 3 / 6$ & \#7F7F00 & \\
\hline
\end{tabular}

pink, red, brown), a combination of them (yellowish grey, orange-red) and a scale o three for each, as light, middle and dark-colour.

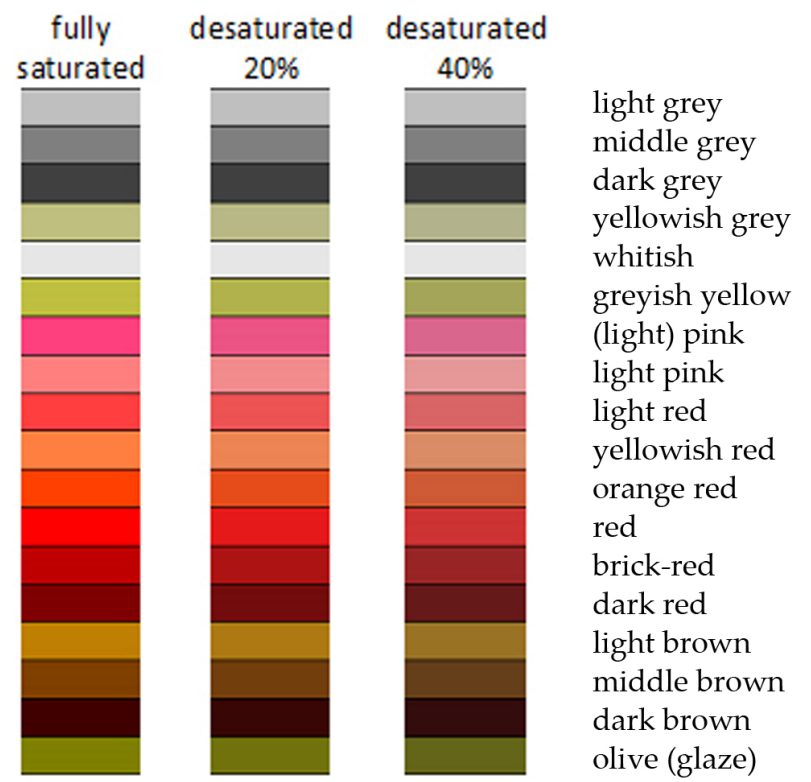

Fig. 2. Saturated and desaturated shades.

There is used the same pack of colours as in the Table 3.

Note that desaturated shades could be apparently lighter or darker as the fully saturated shade.
For this study we obviously cannot use Munsell chart, as we are working with descriptive texts; I am fully aware of how useful and popular within the scientists it is, but I cannot conclude such a long digression on colours without listing here some of the downfalls of the archaeological use of Munsell chart.

First of all, there is no Munsell Chart for archaeology; what we have at hand is a Soil Colour Chart, which is not enough. ${ }^{28}$ Pottery is not just 'soil', but a prepared matter made out of 'soils' exposed to thermic treatment. As a consequence, pot sherds could have more vivid shades than soils. From a theoretical scale of 20 for 'Chroma' (intensity of colour), a soil-colour chart presents shades between 1 and 8 . The pottery scale obviously does not end on the eighth chroma. In order to see more, we would need a full chart, ${ }^{29}$ which works with chroma up to 18 , meaning not only larger expenses (for publication), but also a larger book, more difficult to handle in the repository. Nevertheless, for pottery we would need it, because it can have hues absent in the Soil Color Chart, as red-purple ${ }^{30}$ (Fig. 3).

A second problem is that the matter which we are ${ }^{27}$ Relative equivalent. Some of the shades are absent from Munsell chart. Shades relatively distant of the inscribed codes are noted with .

${ }^{28}$ The observation is not new: SHEPARD 1965, 155, Table 7 and commentaries. See also GERHARZ/LANTERMAN/ SPENNEMANN 1988.

${ }^{29}$ As found on http://oceandatacenter.ucsc.edu/PhytoBlog/Images/Munsell A0[1].pdf.

${ }^{30}$ My option goes for pink anyway, as in the Table 3. 


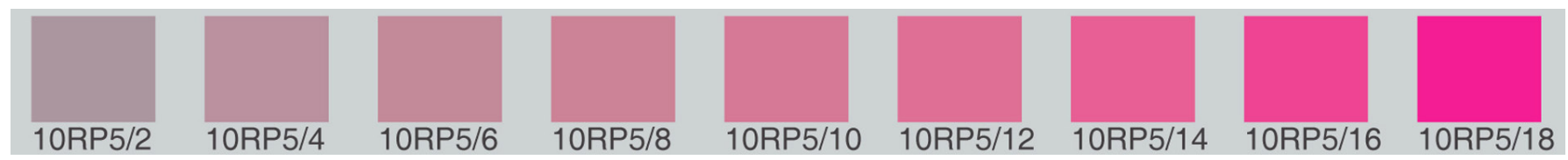

Fig. 3. Full scale chroma for red-purple hue.

classifying is not homogenous, having in fact many shades, although usually related. An antique kiln could not provide a uniform heat and ventilation; when comes to large pots, variation of shades is normal. Which one is the 'true' shade?

A third problem is that we cannot understand well enough the alterations brought to a pot by use, and further on in the post-depositional processes, so different for each archaeological context. We are measuring an altered object, not a new one, but we cannot understand the alteration. What is the point here?

Many shades drive also towards bad statistics, isn't that so? I shall not make here a - necessarily lengthy demonstration, because those accustomed with statistics will surely understand that from 'too many' classes results almost nothing to analyse, with flat figures.

Working with Munsell code is a painfully slow process for big numbers of sherds. For well funded research projects this is not a real problem; for a research environment as the Romanian case, this can be a nasty problem, 'a bridge too far'. Pottery related papers are anyway rare, because a thorough analysis is very slow.

Some limitations and risks could be also read in the pages introducing the Munsell Soil Color Chart. For instance, the light should be white, similar with the sun at noon; but where on the earth surface? Sahara is ok? Much worse, the shades are strongly depending of the humidity of the sample; it shouldn't be wet, but either not dehydrated. What then it is optimal and how can we go there? Can we control humidity within the sherds? The repositories are usually quite dry, therefore the shades quite dull. ${ }^{31}$

I do not advice anyone to give up the Munsell system until nothing better is on the table; nevertheless, we should seriously think about a simplified colour system, possibly more reliable.

\section{FABRIC}

Gheorghe Popilian used only two basic classes: fine and coarse. They are briefly described in the introduction of the all-day-pottery. ${ }^{32}$ The first would be well kneaded, having as temper mica flakes ${ }^{33}$ and very fine sand. The coarse type ${ }^{34}$ would have the ceramic paste mixed with 'pebbles' (therefore supposed added) and it is 'made less careful'. That is all! Some other (few) details could be encountered in the description given for particular types of recipients. For instance, some fine wares could be 'sandy', suggesting a composition containing more sand than usual. The other way around, sometimes the fine ware could be 'chalky' (Rom. cretoasă), meaning soft and leaving a fine powder on fingers, therefore 31 For secondary colouration acquired in repository see GERHARZ/ LANTERMAN/SPENNEMANN 1988, 92.

32 POPILIAN 1976, 84.

${ }^{33}$ It is unlikely for micaceous flakes to have degreasing effect.

34 Named in Romanian '(pastă) zgrunțuroasă', approx. French 'grumeleux', Eng. 'lumpy'. This adjective is endemic in Romanian literature, mainly for antiquity (and post-Roman archaeology). having a relative lack of sand. Similarly, for the coarse class one can meet some sub-classes within the catalogue descriptions. Here and there, in some cases (summing up a small minority) one can read that coarse types could have sand in excess, or pebbles in excess, thus having a higher frequency of relatively large silica, more than usual. Splitting up, one can see finally the next fabrication classes: very fine ('chalky'), fine (regular), half fine ('sandy'), coarse (regular) and very coarse (pebbles or coarse sand in excess), which are five, as in the more recent books.

What one can get is not exactly fabrication types, described each, but loose classes; but this is what Romanian archaeologists did in 1970s or around. I will give further some examples, chosen in order to get some comparisons for what Roman pottery from Dacia is.

Gheorghe BICHIR (1984) was describing the pottery made in the area 'Chilia-Militari' (western and central Muntenia) almost in the same time with the Roman rule north of Danube (half of the second to the late third century). The handmade pottery - of old La Tène tradition ${ }^{35}$ - is taking about $40 \%$ in the settlements ${ }^{36}$ and around $15 \%$ in cemeteries. It was made of coarse paste, sandy, ${ }^{37}$ not very well sorted, containing silica (he said 'pebbles') and sometimes, not often, crushed sherds, fired oxidized but uneven. We have than one class and one variant. The traditionally thrown pottery, i.e. Dacian, is made of fine paste, well kneaded, 'with no additives', reduced fired almost without exception. ${ }^{38}$ This would be the second, dominant class of pottery, taking about $55 \%$ from all thrown recipients. A third type is the kitchen ware, coarse and sandy, 'provincial Roman type', ${ }^{39}$ therefore having all the range of colours - as the model - from grey to yellowish grey and brick-red (no proportions provided). The look of the surface is typical, rough and bumpy. It takes about 35\% from all thrown pottery. This is the picture for the 'Free Dacians', ${ }^{40}$ pretty much the same as in Empire; weird, isn't it?

The picture given by Bichir is largely inherited from the latest phase of the Dacian culture (known also as 'classic', between late second century BC and first century AD). One

35 It is highly questionable if the traditional pottery from southern Romania is ' $\mathrm{La}$ Tène' or not, but in the Romanian literature this equivalence is very fashionable.

36 BICHIR 1984, 30, figure to be taken as a very broad (and relative) value, decreasing anyway for the latest phase. For a very late settlement, as Alexandria, the handmade pottery is only 5\% (TEODOR/BĂDESCU/HAITĂ 2015, 122).

${ }^{37}$ He made anyway an interesting observation: the paste of the handmade pottery from Muntenia is less 'La Tène' than the similar artefacts from Carpi area (Moldova), which is porous and having a slippery touch, the former being sandier (Bichir 1984, 30), much more closer of the Roman model.

38 BICHIR 1984, 34.

39 BICHIR 1984, 37.

40 A largely used expression in the 1970s and 1980s, under the influence of national communism, but possibly later too. As concerns Gheorghe Bichir, he knew exactly how 'free' where those Dacians, but, as many others, he preferred recommended collocations in order to pass his books through the Caudine Forks of the political censorship. 
can find there an 'archaic' type, porous and hand made, fired oxidised. ${ }^{41}$ A second type is made of fine pottery, from a paste 'with no additives', ${ }^{42}$ mainly light grey. ${ }^{43}$ Large storage recipients would be a third class, being possibly made of coarse or fine paste, mainly red. ${ }^{44}$ Painted pottery, extremely rare and only in special locations, is a sub-group of the fine pottery. ${ }^{45}$ Of course, such general facts are not of real help, a study oriented on each particular functional shape being mandatory.

Dealing with the same Dacian 'classic' traditions, but within another geographic area - north-eastern Muntenia - Sebastian Matei (2011) found four classes of fabrication: fine (with no 'impurities', dense and homogenous), halffine (made of a less sorted clay, containing sand, pebbles, calcareous concretions), relatively coarse (pebbles, crushed sherds, shells from the sediment), ${ }^{46}$ and (very) coarse, with a huge amount of temper, which is made of crushed sherds (up to $90 \%$ from the composition!). There are not given any dimensions or a scale of coarseness (Matei 2011, 18). In fact, these are not quite 'classes of fabric', but four basic fabrication types. ${ }^{47}$ The last is quite interesting, because an excess of crushed sherds as temper can be found for at least the next 500 years, in the same area of the country. ${ }^{48}$ The main question here is if the feature is a cultural one, or if the properties of the clay, in the area, require such a massive adding of temper.

A big step forward was made relatively recently by Viorica Rusu-Bolindeț (2007) with a bulky book about the Roman pottery at Napoca. The main fabrication classes are only three (fine, half-fine and coarse), but the author is providing no less than 9 types of fine pottery, 8 types of half-fine and 3 types of coarse pastes only for the oxidised pottery, and another set $(1,2,6)$ for reduced pottery, all having detailed and specialised descriptions. ${ }^{49}$

Coating is also described. For red fine ware, Popilian used the word vopsea (Eng. paint). For fine grey ware Popilian ${ }^{41}$ CRIȘAN 1969, 153; a definition for 'rudimentary and porous' is to be found in descriptions given for early pottery of the second Iron Age, respectively 'having plenty of sand (large) grains and crushed sherds' (CRIȘAN 1969, 68). The frequency is decreasing from rural settlements to the prestigious centres of power, as Sarmizegetusa Regia, where it is almost lacking.

${ }^{42}$ The Romanian expression ('care nu conține nici un fel de ingredient', CRIŞAN 1969, 166, 'containing no ingredients') is identical with that employed by Bichir 15 years later, but by many others. Obviously, it is impossible to determine with the naked eye what is added and what in contained in the native clay.

43 CRISSAN 1969, 167

${ }^{44}$ CRIŞAN 1969, 184

45 CRIŞAN 1969, 197-202.

${ }^{46}$ Meaning a different sort of clay, not used for fine wares.

47 Sebastian Matei has added a comprehensible catalogue (MATEI 2011, 136-287) in which are detailed fabrication matters which allow a far better classification of the fabric, including the colours.

48 The culture Ipotești-Cândești, of the sixth century in southern Romania, was split 'culturally' in two areas: the western side (Ipotești), with Roman type, sandy pottery, and the eastern side (Cândești), more barbaric, with lots of crushed sherds in composition, supposedly of eastern influence (TEODORESCU 1964, 498). The split can be followed throughout ages, from the third and fourth centuries.

49 RUSU-BOLINDET 2007, 60-65. All the process was assisted by professionals in petrography, see the chapter IV (Caracteristici mineralogice și petrografice..., p. 434-457, with the English abstract from the end, p. 457-462). Even so, there are troubles with the decimals, as the compounds from the fine class would be 'smaller than $0.01 \mathrm{~mm}$ ', as well as the half-fine class would have most of its ingredients 'smaller than 0.05 mm' (RUSU-BOLINDEȚ 2007, 61). I doubt that. has used always the word vernis (Eng. varnish). ${ }^{50}$ Both are at least confusing and will be considered all as slips, if a strong hint of other nature is not given. For the last, the 'varnish' look is due to an attentive finishing, by smooth polishing, giving a shiny, slightly metallic look.

\section{METHODOLOGY}

The paper is not a late review of Popilian's monograph; it is just an attempt to turn the book into a working database. I made this writing down all the content of the artefacts' catalogue, into Excel sheets, formalising information and normalising it, using a defined number of fields (columns). The results are displayed in the Annexes of this study, in processed form. ${ }^{51}$ I shall make here some notes in order to help the reader to use them.

I am using here the concept of 'fabrication' in a restrictive way, defining the description of the ceramic paste but excluding the colour and the surface treatment (see Annex 1). It nonetheless deserves its name of 'fabrication', as long as the clay used in pottery shaping is not in its genuine state, but it is worked out, prepared for throwing. There are only two sets of fineness of the paste, 'coarse' and 'fine', having each some variants (as used by Popilian). As the author apparently had no interest in a detailed description of the paste, ${ }^{52}$ he just used instead his experience to stress some cases in which the composition is statistically altered in one way or another, having 'too much sand' or 'an excess of silica'. The classification 'coarse (excess of mica)' will be not be read as 'the only coarse type having mica', as most of the local clays contain mica in some degree. Of course, the value of this information is low, including its statistical outcome. In the same way one will read the group of fine fabrics, where 'fine, with mica' will be not be read as the only containing flakes of mica, but the one on which the mica flakes are easy to see, very obvious. One can find some contradictions in terms, as long as we have a 'coarse type with sand in excess' but also a 'fine type, but sandy'; guessing the way out is a personal choice...

Within the fabrication section we will find also kaolin

\footnotetext{
${ }^{50}$ 'Varnish pottery' is a widespread collocation, especially on auction websites, defining 'something shiny'. The phrase could occur too in archaeological literature within the sense 'coated, shiny' and most of the time dark-grey (WOODLLEY 1911; WAAGE 1939, 541; CAMERON 1986 is providing the multi-lingual equivalence, but not the definitions). Nevertheless, the dictionaries - both for Rom. vernis (from French) and Eng. varnish - tell us that it is a resin (as copal or lac) dissolved in oil or in alcohol, used for protection of a (wooden, usually) surface, for instance on violins. Therefore, it is a shiny, protective thin coating, but not any shiny coating is a 'vernis' or 'varnish'. One would acknowledge also the difference between a varnish and a glazed surface, the last being basically glass; for the last see CVJETIĆANIN 2006, esp. 17-19, but there are no fundamental news, including the thin borderline between slips and glazes (SHEPARD 1965, 44-46). The confusion is not difficult to make, relaying only on the naked eye, as proved by Bogdan SULTOV (1985), which was using systematically 'glaze' for a polished slip. Obviously Popilian took a fashionable word ('varnish') from the literature, used by many for similar situations. On the other hand, resin based coating could be resistant to abrasion, but very likely biodegradable in archaeological contexts (ORTON/HUGHES, 2013, 255); the presence or absence of resins on the surface of the pots is definitely a case for chemists. Seems recommended to use neutral but descriptive collocations, as 'black gloss ware' (PEÑA 2007, $21,159,240$, etc.).

51 And some raw data in a separate, Supplementary file, attached to this paper. ${ }^{52}$ Which is in fact difficult to do on recipients conserved in one piece, as most
} of the items within the catalogue are. 


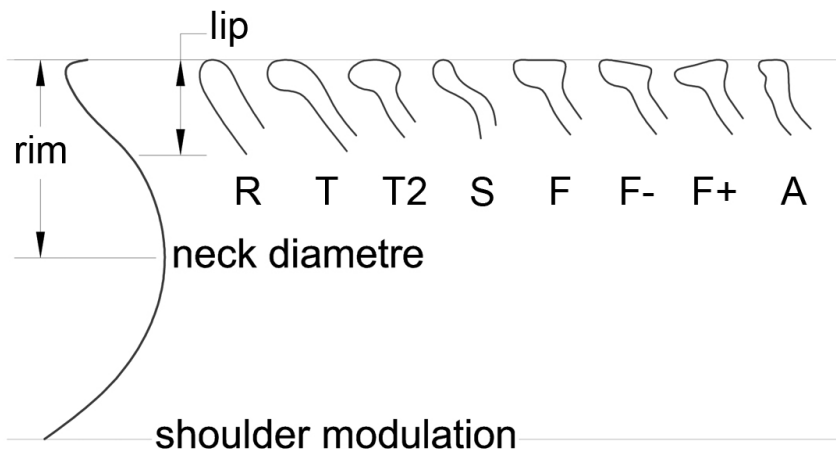

Fig. 4. Rim and lip classifications (see also the Annex 1).

clay, ${ }^{53}$ split in a fine one and a coarse one. Both should be more or less imports, as kaolin is not available in Oltenia, most likely from Moesia inferior (at least from two different areas). ${ }^{54}$ This is a certain hint that some of the all-day pottery was not locally produced.

The Colour section of the Annex 1 presents a grey pack (3 main shades and a borderline shade, yellowish grey) and a large red section, with no less than 6 different shades (close to the maximum perceptible by average people), from (pale) pink to brick-like (the darkest 'red' in Romanian archaeology's tradition), all being, of course, rather conventional shades. In the middle of that table one can find shades resulted from a technological process which was not definitely an oxidised or reducing firing: a pale yellow, a greyish yellow, and three shades of brown. The whitish shade corresponds, of course, to the kaolin clay made pottery.

The surface treatments are not noted in a distinctive field, but advertised by the way of the sign \&; a code as yR\&bR will be read 'a yellowish-red fabric with a brick-red coating'. Of course, such a definition cannot describe the complex technologies of firing pots, alternating oxidised and reducing phases, as such a thing cannot be studied on well preserved or restituted shapes (as most of the pottery used by Popilian in its monograph).

The Annex 1 contains also a large section regarding morphological details as the rim, the base constitution or handles' morphology. Such details are relevant for archaeologists dealing mainly with broken parts, but they were used also by Popilian in making up his classification of the functional types of recipients (see further).

Although the proposed classification is quite basic, far from any sophistication, there are several different

\footnotetext{
53 I am using here 'kaolin' as a generic term. Popilian $(1976,107)$ made it clear that we are not talking about kaolin, but a whitish clay. A difference exists and refers to the concentration of aluminium oxide $\left(\mathrm{Al}^{3} \mathrm{O}^{2}\right)$. If the proportion is over $28 \%$ from the clay's mass, we have proper 'kaolin', very fine and shiny white, as porcelain is. 'Kaolinite clay' (or whitish clay at Popilian) has a concentration of aluminium oxide around $20 \%$, while a regular clay has around $10 \%$ (thanks to Dr Valentina Cetean for sharing to me those basics about whitish clays). Of course, Popilian did not make such measurements, in the early 1970's, therefore any specific term is doubtful. Sherds of so called 'kaolin', of Roman age, I've seen so far, are not that white and not very fine, therefore Popilian might be right.

54 Areas rich in kaolin are to be found in Dobrudja, between Cernavodă and Constanța (see Geological map of Romania, http://www.geo-spatial. org/download/harta-geologica-a-romaniei-scara-1-200-000), but looking at the map, at the lower Olt River area whitish pottery is more likely of NorthBulgarian origin, from sources around Novae (DASZKIEWICZ/BOBRYK/ SCHNEIDER 2010, mainly 38 and 45 with the map from the Fig. 6).
}

components dealing with the rim and the lip. Figure 4 is presenting the definitions used for the rim (the upper end of a recipient) and the lip (the termination of the rim, sometimes corresponding to a specific use). There are three evaluations to do, for the next: height of the rim; height of the lip; bent of the rim. All three are using a scale of four terms, from 0 (zero) for 'null' to 3 for 'great'. The result has the form ' 321 ', to be read 'high rim, balanced lip, small bent'. After this evaluation of the proportions, comes next a sketchy classification of the lip's section (see Fig. 4 and Annex 1, 'lip morphology').

The classification of the recipient's basis is simpler, looking only at two parameters: the geometry of the lower panel of the body (plain, recurved and profiled, see Fig. 5) and the geometry of the external face of the bottom: flat, with central cavity or standing on a ring. Of course, such a classification of the bases could be more complicated than that, but working with well preserved pot shapes (Popilian's case) one cannot be sure about the inner configuration of the bottom. Therefore, it was skipped from the criteria of classification.

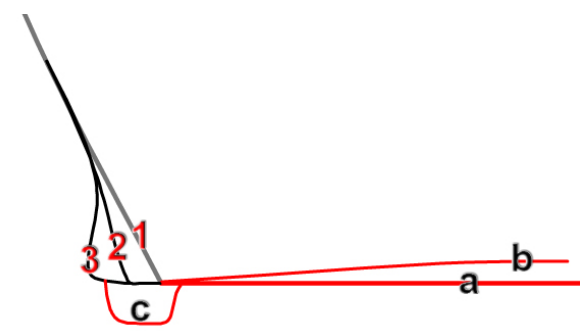

Fig. 5. Parameters used in bottoms' classification (see also the Annex 1).

Getting codes for handles has proved a complicated matter. One has to note both the lower and the upper points of attachment (Annex 1, 'handles'), the direction of the lower part of the handle, the way it bents (simple arch, super-arched, angular) and the handle's section. The resulted code is rather long and difficult to read.

The decoration of the Roman pottery from the Principate age is usually a simple one, mainly talking about the all-day utilitarian recipients. The classical soul of the early Empire culture is expressed in the reserved use of decorative means. Most of the pots are not decorated at all, when not restrained to a simple groove circling a key point of the shape, as the outer lip or the shoulder. Note that some manipulations of the potter's wheel, as the ridges, the ribs or the thresholds are considered 'decoration', as their presence on the shape has no functional meaning.

\section{STATISTIC DATA}

The Annex 2 is presenting an overview of the utilitarian types in discussion, with bilingual terminology, in order to clear the translation options I made, but also to ease the foreign researcher's access to the original text. Not all the catalogue made by Popilian has been formalised and processed for this paper, but the types with a relevant statistical presence.

The Annex 3 is an illustrated typology, as provided 
by the author of the monograph. A very short description is given, following Popilian's presentation for each type, including the spatial distribution and the supposed chronology. There are collected all types which are not made of a single artefact. ${ }^{55}$ I choose the illustration for each type trying to select the most representative, middle sized item, scaling all for pictures at the same size, about 1:5. Each drawing is originally labelled with its number into the catalogue. Each class of recipient is rendered both in the original (Romanian) word, as well as in English.

Jars are usual shapes in Roman Oltenia, collecting $14.9 \%$ from all analysed pottery. The many are handless jars, followed by double handled jars and simple handled jars. They seem to be more or less specialised, as the jars with one handle are always coarse and grey, meant for cooking. ${ }^{56}$ A relative homogeneity can be observed for the other categories, as most of the handless jars are grey and coarse, and almost all double handled jars are red and fine. A certain 'interbreeding' process can be spotted out for both categories, as the types 10 and 11 of the handless jars are made out of fine paste, as well as two isolated items of the second and third types of the double handled jars are made of coarse matter (See Annex 4). The mixed features can be understood as 'influences' or special functions (difficult to guess), but also as technological failures, as exemplified by 4 items from the first type of the handless jars, with shades of colour at the fringe between a reductive and oxidised firing: grey yellow and brown. All handless jars seem meant for using in the kitchen. ${ }^{57}$

The typology proposed by Popilian is not inspired by the general morphology - considered dull - but by some details as the configuration of the rims, lips or bases. ${ }^{58}$ In practice, the criteria seem many and uneven, from case to case. For instance, looking at the Annex 5 (jars' typology), one can see that the double handled jars' typology is highly dependent on the configuration of rims, lips and bases; the same thing is yet not true for the entire list of the handless jars, where all those criteria (but also fabrication, colour) are really not homogenous. The type 1 seems made entirely on the general morphology, with a very low median diameter. Strong reasons connected with the general shape and proportions seem to be also at the origin of the classification proposed for the double handled jars, as illustrated by the differences between the types 2 and 4 (see Annex 3).

The size of the pots - including the capacity - could put a light on their utility. The range of the handless jars' capacity is as different as 0.31 at minimum and 8.211 at

\footnotetext{
55 Types made of a single artefact are considered irrelevant for local/regional production. Our final purpose is to understand what exactly means 'Roman pottery in Dacia Inferior', or, more precisely, in Oltenia, as expression of the 'Provincial culture'.

56 The homogeneity of this group is remarkable (and quite rare), as all the artefacts are sharing the same short rim (encoded 122), with a thick lip (B) and are always decorated with grooves all over the body.

57 This is a rather raw conclusion, as they have no handle and are difficult to be manipulated when hot. This is merely an ethnographic problem, than an archaeological one. An archaeological question is if they are wearing marks of use in hot environments, like flame marks or smoke on the lip (due to the use along a lid), but this is not that easy to be answered on small sherds or even in completed and heavily restored pots.

58 POPILIAN 1976, 86.
}

maximum ${ }^{59}$ suggesting different utilities (Annex 6). Some of the types are rather small (as $\mathrm{j} 1$, with an average of 1.35 1), others are mostly middle sized (j2-j7, between 2.3 and 3.8 1). In the list one can find even a type with a good statistical occurrence (7 items), with an average capacity of 5.11 l; we remember yet that the type $\mathrm{j} 10$ is made out of fine paste, thus very likely it is not meant to boil things. ${ }^{60}$

For jars with one or two handles I do not have an estimation of capacity, but the heights are available and they are a pretty fair term of comparison, as the shapes are relatively alike. The single handled jars (type js) are the most homogenous type of all, being similar with the type $j 1$, of small capacity. This unusual homogeneity could recommend a certain workshop from eastern Oltenia.

Double handled jars are made mostly from fine paste, thus their utility seems rather connected to the storeroom than to the kitchen. Their distinct morphology (including lip's shape) is suggesting different utilities, like keeping liquid (like water, see jd1), mixing wines (jd2) or edibles (jd4).

The containers meant for keeping, pouring and serving liquids are summing over half of all the evidence under analysis (Annex 2: beakers, flagons, small beakers, cups).

The shapes considered by Popilian as beakers ('căni') are just some above $1 \%$ of all. They could be both, grey (types $1,2,4)$ or red (type 3), from fine paste, with well-balanced proportions, having as key term 'two thirds': base diameter is $2 / 3$ from the rim diameter, which is $2 / 3$ of the median diameter, which is $2 / 3$ of the height. The sizes are ranging from 0.51 to 2.31 (loose estimations), with one exception (cat. 417) having over 91 . Note that the general morphology of the beakers is different than what was labelled further by Popilian as 'small beakers'; therefore, the small beakers are not just smaller, but have different constitution and surely different function.

Flagons are the most popular shapes within Roman Oltenia, collecting over $22 \%$ of the stuff. Most of them are simple handled, with fine fabric, and reddish (with only 5 grey exceptions, out of 114). Most than half (68) are recorded as having a slip, but the real rate could be greater, because the flagons are - unequivocal - recipients for liquids and should be not porous. The slip is always from the same basic colour as the main fabric (grey of red), but the relationship between the two (fabric and slip) is to be taken as less granted, as both categories are largely served by stereotypical descriptions, as 'the brick-like paste' (for the main fabric) and the 'red paint' (for coating). The difference of shade between the fabric and the slip could be due to diverse causes, such as a different chemical composition of the clay, or a short oscillation of oxygen flowing into the kiln, near the end of firing process, thus no inference is recommended. Only more detailed observations could make a distinction between the two.

All double handled flagons are made of fine paste, and, with one exception, are red (26).

\footnotetext{
59 The capacity is calculated with the Compass methodology (TEODOR 2000), with expected errors around $2 \%$. The average error was established versus AutoCAD measurements,

${ }^{60}$ For the variability of ceramic paste versus the intended function, see BRONITSKY/HAMER 1986, esp. 92, 94; FEATHERS 1989, esp. 582; ARNOLD 2000, esp. 345.

${ }^{61}$ Meaning the sixth part of a congius, or 0.5461 for sextarius.

${ }^{62}$ The artefact from the catalogue number 693 is ascribed to the type 3
} 
Table 4. Distribution of the classes of capacity for Roman flagons from Oltenia

\begin{tabular}{lccccccccccc}
\hline sextarii $^{61}$ & 0.5 & 1 & 2 & 3 & 4 & 5 & 6 & 7 & 8 & 9 & 10 \\
\hline items & 4 & 52 & 29 & 11 & 8 & 5 & 2 & 0 & 0 & 1 \\
\hline percent & $3.5 \%$ & $46.0 \%$ & $25.7 \%$ & $9.7 \%$ & $7.1 \%$ & $4.4 \%$ & $1.8 \%$ & & 1 & $0.9 \%$ & $0.9 \%$ \\
\hline
\end{tabular}

Table 5. Typology of the small beakers

\begin{tabular}{llll}
\hline typology & decoration & items & other facts \\
\hline one handle & & & \\
\hline type 1 & absent & 24 & or an incision marking the neck \\
\hline type 2 & ridge on the neck & 30 & kaolin \\
\hline type 3 & grooves on the body & 52 & elaborated lips \\
\hline type 4 & grooves on the body & 15 & \\
\hline types 5-7 & absent & 5 & morphology following the two handled jars (mainly type 1) \\
\hline two handles & & & morphology following the two handled jars type 462 \\
\hline type 1 & absent & 3 & 9 \\
\hline type 2 & absent & &
\end{tabular}

As concerns the rim configurations, almost all types of beakers have tall rim, just a bit reverted. Similar height of the rim can be seen for single handled flagons from types 1,5 , and 12, but all others are shorter (see Annex 7, rim configuration). Lip configurations are also well sorted along the types of beakers and flagons. Simple rounded lips are specific for beakers and the first type of flagons, $S$ shaped mainly for the large group of the second type of flagons, flat lips for the flagons types 3,5-7, beaked rims are all of the type 12, bilateral thickening go for double handled flagon type 6 , and a lip with the external face shaped like an accolade with type 2 of the same double handled flagon (Annex 7, lip configuration). Such statistics could be annoying for the reader, but also can be of a great help when dealing with sherds, even when the handle is absent.

Just a few words about the section of the handles, in general. At the end of the Annex 1 the reader will find a sketch for coding the sections; no data about handles' sections will be presented in the rest of the Annexes, as the analysis showed that they cannot contribute - at least in this stage of the research - to the aims of this study, for instance identification of pottery types just looking at a handle, and unfortunately this is true of any of the classes having a handle (handled jars, beakers, flagons). As a general rule, they are proportionally with the recipient, the section being rather round for small objects, and flat for large ones. ${ }^{63}$ The only type of decoration they have is longitudinal grooving, from one to three (or even four) lines, depending on the width of the handle; but the actual number of grooves varies for each class and type in an incomprehensible manner. This is true even for extremely homogenous types, as the one handled jars, for which I could count a D shape section, 7 cases with a simple groove, but also two cases with a double groove (an another two undetermined). It seems that for the (Popilian 1976, 204), but is missing from the comments and description related to various types (Popilian 1976, 108-109, ending with the type 2); this is very likely a typing error, as the object fits very well the second type.

${ }_{63}$ This is not true for amphorae, but they are not making the object of this paper. potters who made them (and also for their customers) the morphology and decoration of the handles were not relevant. For this specific case, their link to the single handled jars is suggested by their fabric, coarse and grey. Further on is not that simple, because between a handle of a beaker and one from a doubled handled jar there is no difference.

Several years ago I wrote about the capacities of the Roman flagons from Oltenia, sparing here the necessity of long considerations. ${ }^{64}$ I will retake here only some of the data (see Table 4).

As the flagons smaller than a sextarius are very likely errors of drawing or calculation, the smallest capacity of the flagons is for one sextarius, ${ }^{65}$ gathering half of the known recipients. Another quarter of the evidence is given by flagons equivalent of two sextarii. Large vessels, as around 10 sextarii are not missing as well, as we already saw for beakers. From a statistical point of view, those larger recipients are irrelevant, the 'Roman' flagons being equivalent of one or two sextarii. As a consequence, flagons are meant for personal consumption of liquids, most likely wine, in usually small quantities, adapted to a relatively poor market. This is a definition which does not work for Barbaricum, where the consumption norms were clearly different, probably socially restricted but with generous capacities.

One thing is yet to be considered later: most of the discoveries presented in the Popilian's catalogue are coming from burials (or chance discoveries). We have to ask ourselves if the funeral inventories are not 'symbolic', recalling the habits of the deceased; are those items full size objects, from the real life, or not? ${ }^{66}$ Without detailed observations of each recipient such a problem cannot be solved; how many 'new'

\footnotetext{
64 TEODOR/BĂDESCU/HAITĂ 2015, 105.

65 As they were surely used in places as taberna, the recipients should have relatively straight capacities, closely related with the Roman system of measures.

${ }^{66}$ How many pots from the funerary inventories are of the sort known as 'funerary pottery', made new for ceremonial purposes? Apparently not many (RUSU-BOLINDEȚ 2014, 345, 352; DANANAI/DERU, 2018, \$ 4); but how many? Are they full size objects or not?
} 
and rather porous (thus 'symbolic') flagons are they in the funeral use? There is no answer for that, just now.

Comes next a bulky ensemble of small drinking recipients, such as small beakers with one or two handles, cups and clay glasses, summing up almost $29 \%$ of the analysed pottery.

In defiance with their given name, the small beakers are following rather the morphology of the jars. One handled small beakers are the most numerous category within Popilian's catalogue, collecting almost one fifth of all recipients. The criteria used by the author were different in each case, because the single handled beakers are grouped following decoration, but the double handled beakers - the morphology (Table 5).

With only one exception, all the small beakers have a fine fabrication. As a general rule, they are reddish, but greyware occur, here and there, in almost all types, giving $12 \%$ from all. As grey small beakers did not group on other criteria, ${ }^{67}$ they are rather technological errors, than a specific influence from elsewhere.

As concerns the dimensions of the small beakers, they are almost all ${ }^{68}$ smaller than a sextarius. As I did not make proper measurements, only rough estimation, ${ }^{69}$ I cannot provide their classes of capacity (if any), but they are all divisions of sextarius, and very likely were not used in trading liquids, but for households purposes. ${ }^{70}$ The average capacities for the main four types of single handled beakers are the next: 0.341 for type $1 ; 0.211$ for type 2; 0.251 for type 3 and 0.241 for type 4 . Let's note here that the type 3 seems to be a local copy of the imported type 4 (kaolin), ${ }^{71}$ and, by fortune or not, they have the same estimated average capacity.

The 'cups' are rather an artificial category, as the defined types are coming from 4 completely different shapes (see Annex 3): type 1 is following the Dragendorf 33 terra sigillata cup $^{72}$ (type 2 is only a larger variant), which is an 'open form'; types 3-5 follow the morphology of the small beakers, but having no handles; ${ }^{73}$ type 6 is rather a miniature replica of the bowls (having yet handles), with the height almost half of the median diameter; type 8 is a clay replica of the drinking glasses, a tall open shape. Of course, they could serve the same purpose, as small drinking recipients, as well as the small beakers; but this term, 'cups', is just an umbrella word, for the sake of a 'classification'.

The storage recipients are missing from my statistics, just because of their small numbers. They are rather storage jars, than proper dolia, serving more for household purposes than for community's reserves. ${ }^{74}$

Turibula are open shapes, with a truncated cone shape, standing on a well developed foot, with a large (or

\footnotetext{
${ }^{67}$ I have chosen not to publish the annex data, because it proves nothing else.

68 Except two (catalogue 567 and 670).

${ }^{69}$ Based yet in their main dimensions (height, the three diameters), collected from the catalogue or from the drawing.

70 Again, most of them were found in funeral contexts, for which the real capacity does not matter.

${ }^{71}$ Most of the analogies Popilian knew were from Moesia Inferior, especially along Danube, missing in Transylvania (POPILIAN 1976, 107). I am repeating here that 'kaolin' is here a generic term, Popilian speaking about 'whitish clay'. 72 POPILIAN 1976, 109; see also http://potsherd.net/atlas/types/sigillata/ gallery\#tsforms-17; OSWALD/PRYCE 1920, 189, Plate LI.

${ }_{73}$ POPILIAN $(1976,111)$ saw the type 5 rather as a miniature handless jar.

74 TEODOR/BĂDESCU/HAITĂ 2015, 127-128.
}

double) lip, decorated with pinches and cuts. Their function was - and still is - far from clear, Gh. Popilian crediting their censer utility ${ }^{75}$ but recent studies show that extremely few of them had smoke marks on the inner side. ${ }^{76}$ From my point of view, turibula known from Principate age are too open to protect burning matters from the air flows, therefore the Latin name should be kept in use. At the Lower Olt River there are basically three types of turibula: red and fine (type 1), grey and coarse (type 2), ${ }^{77}$ and with a shorter foot (type 4, very likely of southern origin), type 3 being a unique item, probably import.

Turning back to the supposed function of turibula, I have to say that 'censer' could be also lots of other recipients from Popilian's catalogue, especially small beakers or cups, especially when provided with handles, because such small pots do not need handles when cold.

We will go further with other open shapes, very numerous, used for serving meals. First of all I need a detour about the Romanian language commons, because those names occur in archaeological classifications. ${ }^{78}$ 'Castron' is a large bowl, used for bringing the soup at the table, connected merely with the urban culture. ${ }^{79}$ 'Strachină' is a traditional word for a large and deep dish used both for individual or family feeding. ${ }^{80} \mathrm{~A}$ third one is 'farfurie', which is simply a dish (almost flat, with short tilt sides). Looking at the shapes classified by Popilian, I searched for an easy and understandable translation; therefore I have translated the first two as 'bowls', as both have (almost systematically) a 'maximum diameter' just below the rim. Following the Romanian language rules for 'castron' and 'strachină' I made two categories named 'deep bowls' and 'shallow bowls'. This is good as a translation, but not great as proportions, as seen in the next graph. From the image at the Figure 6 we can clearly see that we have also two different classes of dishes: with a large base (noted 'dishes 1') and a smaller base

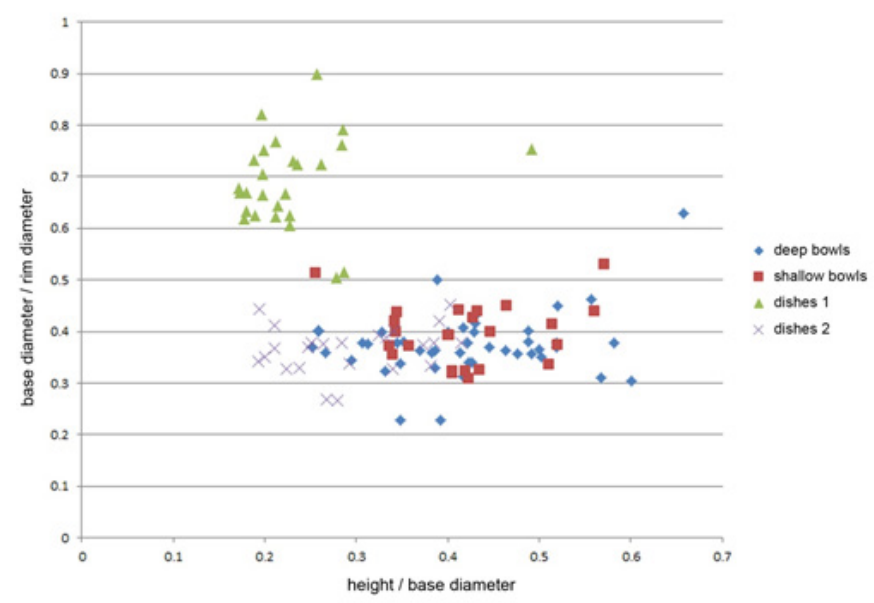

Fig. 6. Graph showing the proportions of 'bowls' and 'dishes'.

\footnotetext{
POPILIAN 1976, 117

${ }^{76}$ RADU 2014, 101.

77 Why would be a censer made out of coarse paste?

${ }^{78}$ A similar discussion about large or small bowls, and differences between the Roman and Barbarian classes of size, in TEODOR/BĂDESCU/HAITĂ 2015, 110-111.

${ }^{79}$ Nevertheless not very recent and with debatable origin.

${ }^{80}$ Its pretended neo-Greek origin is not of much help, because the word is certainly older than neo-Greek influences, from $18^{\text {th }}$ century onward.
} 


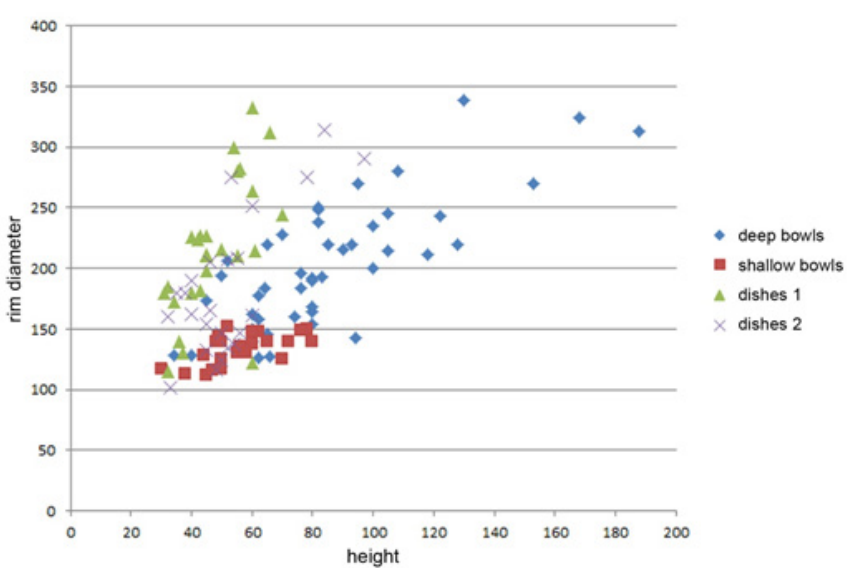

Fig. 7. Graph showing the main dimensions of the bowls and dishes ( $\mathrm{mm}$ )

diameter ('dishes 2'), resembling the rest of the recipients. From the first category are the dishes from the types 6 and 7, the rest going for the second (see also Annex 8).

Looking at the graph from the Figure 7 we can see also than probably a better translation would be 'large bowls' and small bowls', although there are no clear cut limits of the definition. The author himself repeatedly said that the distinction between the 'deep bowls' and 'shallow bowls' is difficult to make. ${ }^{81}$ Saying that - and stating that differences are difficult to make, I will resume here the main traits of the bowls, as explained by G. Popilian:

deep bowls ('castroane') ${ }^{82}$ :

type 1: thickened lip; a strong ridge on the maximum diameter; type 2: similar as general proportions, but missing the things mentioned above;

type 3: flat oblique out turned lip; very rare;

type 4: open shape, thin rims, a ridge is clearly marking the median diameter; rare;

type 5: closed shape, out turned rims, flat bottoms; jar like, but short; coarse fabric;

type 6: hemispheric, outer rim with grooves; fine

type 7: similar with 6 , but very wide and short;

shallow bowls ('străchini') ${ }^{83}$ :

type 1: similar to deep bowls, type 6, but smaller (height below $5 \mathrm{~cm}$ );

type 2: similar to deep bowls, type 5, but smaller and from finer fabric;

type 3: 'similar to deep bowls, type 7' (?)

As concerns the fabric and colour of the open shapes, they are generally fine and red (Annex 8, the first table). Exceptions are the fifth type of the deep bowls, and the types 1, 4 and 5 of dishes, all of coarse fabric. Grey coloration could occur here and there, without a clear rule, most like as technological failure, except the type 5 of the deep bowls (11 from 14), dishes type 1 (6 out of 7), 4 and 5 (8 out of 10). Whitish items, more or less 'kaolin', are 5 dishes from the third type (with no replica on local clay), and one item at the type 5 (most likely a raw model for the local production).

Open shapes have little or no rim, except some definite types, as the fifth type of the deep bowls, the third, sixth and seventh types of dishes (Annex 8, second table), important 81 POPILIAN 1976, 118, 122.

${ }^{82}$ POPILIAN 1976, 118-122.

${ }^{83}$ POPILIAN 1976, 122-123. details when dealing with broken parts, as the type 5 of deep bowls is made of coarse paste, but the mentioned types of dishes are not.

The most common configuration of the open shapes is standing on a ring; the only ring much smaller than the lower body of the recipient is to be seen on platters (Annex 8, third table). Exceptions are the type 5 of deep bowls (coarse fabric) and most of the dishes (types 1-5). The last two types of dishes (6-7) are neatly different, inviting us to ask ourself if their place wouldn't be rather along the shallow bowls.

The decorative patterns of the open shapes are the same simple ones as almost all the pottery of this age. The most common case is the absence of decoration (75 out of 135), dominating the classes of shallow bowls (except type 3 ), dishes (except type 2) and platters. Working on sherds decoration will be not very helpful, except the very specific cases of the dishes from the types 1 and 3 .

The lids are the last class of proper Roman pottery from Oltenia. The shape is dull, conic, with a small cylindrical handle. A small variation can be observed for the rim, more or less thickened lip, more or less turned inside. This is the only class of pottery without a clear relationship between the fabric and the basic colour, all combinations being possible (fine, red or grey, coarse, red or grey), showing - in my advice - the fact that they were meant to serve very different kinds of purposes (for cooking, for storing edibles or liquids).

I shall end this section with just a few words about the Dacian pottery grouped at the end of Popilian's catalogue (nos. 937-959). Traditional Dacian pots came up from all sort of social environments, as rural settlements, forts or even towns, but the artefacts from the catalogue are from the rural necropolis at Locusteni. ${ }^{84}$ Oltenia does not make an exception with its - limited - occurrence of traditional local pottery, as similar discoveries are known for Transylvania too. ${ }^{85}$ What seems interesting to me are the notes made by Popilian, here and there, when comes to influences played by both cultures - Roman and Dacian - one to another. Such cases are some 'Roman' types, suspected to be born under Dacian influence, as would be the type 7 of the handless jars, the type 11 of the double handled jars, or type 1 of the deep bowls. ${ }^{86}$ But the most puzzling case is that of the lids, about he was writing that 'As concerns their origin we can see a continuity of shapes from the late Dacian age, although probably they appeared under Roman influence.${ }^{87}$ Matter less if Popilian was right or wrong in one particular case or another; what really counts is that he felt the 'Roman' pottery as a sort of cultural interbreeding. This is the way one should conclude what a 'Roman provincial culture' is.

\section{CONCLUSIONS}

As this is not a proper 'study', but a database with a story, it shouldn't have 'conclusions' written by the author, but by the reader. The outcome is yet bulky and difficult to

\footnotetext{
${ }^{84}$ POPILIAN 1976, 132.

85 RUSU-BOLINDET 2014, 248-249.

86 Worth mention the cases when the distribution of the known analogies are suggesting a regional origin (handless jars type 11, single handle jars, type 4 of the double handled jars, type 7 of flagons, etc.). Of course, all those distributions should be checked against the more recent evidence.

87 POPILIAN 1976, 127, note 170, citing the master of the Dacian pottery,
} Ion Horaţiu Crişan. 
follow; therefore the author is going to deliver here what he is thinking it finally came up on quite an old project, made with large interruptions through years, which is not the ideal way to do things.

The monograph published by Gheorghe Popilian in 1976 is still the best book about the Roman pottery in Dacia, looking at the number of citations. The book is yet old, written in the style of the old school of archaeology and needs some 'translations', in order to be useful further.

Popilian published a great collection of pottery, almost 1000 artefacts, most of them recipients in one piece (even repaired). As such a state of preservation usually defines funerary archaeology, one has to keep in mind that at least some of it could be funerary production, therefore of lower sizes and quality than the average pottery sets from everyday life. Worse than that, the frequency of the main functional types seems to be different in the realm of living. There are no studies about the differences between the pottery sets from cemeteries and those from the settlements, ${ }^{88}$ but I can give some examples from my experience with some Roman camps. For instance, the small beakers are far less present on the military sites than in Popilian collection; vice versa, the storage vessels are far many. ${ }^{89}$

As I was interested in local production - in order to define 'a Roman provincial culture' - I dealt only with all day pottery (catalogue no. 315-959).

Popilian has used a conventional set of colour names. The Facebook test made for the perception of the shades put me in front of striking evidence: the archaeologists are using a different set of names than all the others. Therefore Popilian's set of the colour-names is not 'natural', as one could guess for someone before the Munsell Code; it is in fact strongly attached to a bookish tradition from the own culture. This is why a 'translated' version of the book is not enough; it must be explained, both for the foreign archaeologists and for the younger Romanian specialists, many of them with studies abroad, but with few or no experience back home. For instance, when Popilian was writing 'paint' one has to read 'slip' (coating). Similarly, would be wrong if you would think that a 'red slip' is lighter than a 'brick-like' ceramic body, due to 'speaker-sensitivity': the slip is just finer and much diluted, 'paint' like. ${ }^{90}$

The old master of the Roman pottery from southern Romania used limited types of fabrication in his descriptions. In fact, the basic fabric types 'fine' and 'coarse' make together

\footnotetext{
${ }_{88}$ But which kind of settlements? Of what chronology? From where?

89 Beyond the split between cemeteries and settlements, there is a variation of frequency between the main vessel forms in use across centuries, inside the same culture (COOL 2007, 228, Table 19.2). In Roman York, for instance, beakers are many in the third century, flagons in the second century, as well as bowls, etc., with strong variations, as 1 to 9 for beakers or 2 to 10 for jars. The chronologies given by Popilian could and must be refined. In order to achieve that one needs more publications regarding the complete set of pottery from well dated contexts.

90 In the weeks after I sent this paper to the editor I took many snapshots using a microscope for the Roman age pottery from the Băneasa fort (Teleorman County, east of Olt Valley). The outcome, on short, would be that what Popilian named a (red or dark-red) 'paint' is really a paint (for which a brush was used), not a clayish coating (finished with a wooden spatula). On the other part, the paint is always applied over a very fine slip, not directly on the main body of pottery, even a thin one. Any part of the present text contradicting this statement will be disregarded.
}

about $80 \%$ from all stuff. Accidental mentions of a sort of excess - of sand or of mica - do not make relevant categories, but rather are pointing out technological failures. These basic categories are still useful, I think, as the recent archaeology works with much detailed descriptions of fabrication, but always classified them as 'fine' or 'coarse'. ${ }^{91}$ Although incomplete, this type of information is definitely useful.

In order to get a statistical view I had to make a normalisation of data, as well as a codification (see the section Methodology). Intending to avoid a complicated classification, I split up the fabrication and the colour issues in two separate tables (see Annexe 1), although in the international literature they are usually taken together. This couldn't be a problem by itself, as the diversity resulted at the intersection of clay fabric and colour is displayed in analysis (see Annex 4).

Classification (and codification) of the parts of the pot, as the rim-lip and base shapes, are rather intricate, though intended simple. They are yet critical important, as such data was used by Popilian in order to make up its own classification of the pottery types. They are also very important when dealing with broken parts.

Annex 2 is bringing bilingual terminology in naming classes of pots, as well as the share of each in this collection. The most frequent are the small beakers, the single handled flagons, the jars, the dishes, the bowls, and the cups; due to the numbers, they could be taken as representative for the local production. Their typology can be also considered stable and clear, except the 'cups', which are rather and artificial category, but some issues about the open shapes can be also mentioned.

Annex 3 is an illustrated typology, aiming to ease the understanding of the classification system proposed by Popilian; it is not always easy to follow, and not fully logical (although 'historical'). For instance, the small beakers are not following the morphology of the beakers, but those of the jars; although sharing the same name, the simple handled jars and the double handled jars have not only different morphology, but also divergent fabrications, having certainly different uses. Also, the statistic of the main dimensions proves that the classification of the bowls and dishes is rather random, just a 'choice' made by the author.

Such statistics could look technical and fastidious. The real value will be hopefully proved in comparative data, as the case with the Roman pottery found east of Olt River (therefore 'out of' Oltenia). The distributions of the pottery classes, fabrications types and colours are unexpectedly different, as the fort of Băneasa is located less than $20 \mathrm{~km}$ afar from Olt River. These differences could be due to the chronology, to the military environment, but surely to another 'provincial' culture. Yet to come.

\footnotetext{
${ }_{91}$ As we already seen, some archaeologists are using half-tones, like half-fine or half-coarse. In practice, many they are, the thinner (and blurred) the line in between is. Preparing the report for the pottery from Băneasa (diggings from 2017, in progress) I used very detailed descriptions, and the outcome is simple, that the line between 'fine' and 'coarse' is rather imaginary, with many fabric types in the border area. Finally, I concluded that the 'impression' (of fines or coarseness) is more important than the analytic view. After a long detour, I came back to the basic terms of Popilian. Of course, the detailed description of the fabrication types are still very useful, mainly when speaking of the fabrication sites, in order to recognize the 'imports' elsewhere (see, for instance, MARSH/TYERS 1976; DAVIES/RICHARDSON/TOMBER 1994).
} 


\section{REFERENCES}

ARNOLD 2000

Arnold, D. E., Does the Standardization of Ceramic Pastes Really Mean Specialization?, Journal of Archaeological BICHIR 1984 Method and Theory 7/4, 333-375.

Bichir, G., Geto-dacii din Muntenia în epoca romană (București: Editura Academiei).

BRONITSKY/HAMMER 1986

Bronitsky, G./Hamer, R., Experiments in Ceramic Technology: the Effects of Various Tempering Materials on Impact and Thermal-Schock Resistance, Americal Antiquity $51,1,89-101$.

CAMERON 1986

Cameron, F., Dictionary of Roman Pottery Terms, Journal of COOL 2007 Roman Pottery Studies 1, 58-79.

Cool, H. E. M., Eating and Drinking in Roman Britain, Cambridge (New-York: Cambridge University Press).

\section{CRIŞAN 1969}

Crișan, I. H., Ceramica daco-getică, cu privire specială la Transilvania (București: Editura Științifică).

\section{CVJETIĆANIN 2006}

Cvjetićanin, T., Late Roman Glazed Pottery. Glazed Pottery from Moesia Prima, Dacia Ripensis, Dacia Mediterranea and Dardania (Belgrade: National Museum).

DANANAI/DERU 2018

Dananai, A./ Deru, X., Pottery Function, Dining and Funerary Assemblages. A comparative study from northern Gaul, Internet Archaeology 50.

DASZKIEWICZ/BOBRYK/SCHNEIDER 2010

Daszkiewicz, M./Bobryk, E./Schneider, G., Composition and technology of the Lower Danube Kaolin Ware (LDKW). Examples from Novae, Bulgaria, Rei Cretariae Fautorum Acta 41, 37-49.

\section{DAVIES/RICHARDSON/TOMBER 1994}

Davies, B. J./Richardson, B./Tomber, R. S., A dated corpus of early Roman pottery from the City of London (London: Museum of London).

FEATHERS 1989

Feathers, J.K., Effects of Temper on Strength of Ceramics: Response to Bronitsky and Hamer, American Antiquity 54, 3, 579-588.

GERHARZ/LANTERMAN/SPENNEMANN 1988

Gerharz, R. R./Lanterman, R./Spennemann, D. R., Munsell Color Charts: A Necessity for Archaeologists?, Australian Journal of Historical Archaeology 6, 88-95.

MARSH/TYERS 1976

Marsh, G., Tyers, P., 1976, Roman Pottery from the City of London, Transactions of the London \& Middlesex Archaeological Society 27, 228-224.

ORTON/HUGHES 2013

Orton, C./Hughes, Pottery in archaeology (Cambridge-New York: Cambridge University Press).

OSWALD/PRYCE 1920

Oswald, F., Pryce, D. T., An introduction to the study of Terra Sigillata (London: Longmans, Green and Co.).

PEÑA 2007

Peña, J. T., 2007, Roman Pottery in the Archaeological Record (New York: Cambridge University Press).

\section{PETOLESCU 2010}

Petolescu, C. C., Dacia, un mileniu de istorie (Bucureşti: Editura Academiei).

\section{PETOLESCU 2018}

Petolescu, C. C., La romanité daco-mésienne et l'ethnogenèse de roumaines (București: Editura Academiei).

\section{POPILIAN 1976}

Popilian, G., Ceramica romană din Oltenia (Craiova: Scrisul românesc).

\section{RAYNER 1994}

Rayner, L., Guidelines for the Archiving of Roman Pottery. London Archaeological Archive and Research Centre.

\section{RUSU-BOLINDET 2007}

Rusu-Bolindeț, V., Ceramica romană de la Napoca. Contribuții la studiul ceramicii din Dacia romană (Cluj-Napoca: Mega).

RUSU-BOLINDEŢ 2014

Rusu-Bolindeț, V., Pottery in funerary context - some aspects of conviviality in Roman Dacia, Studia Universitatis Babes-Bolyai, Historia 59/1, 2014, 239-284.

\section{RADU 2014}

Radu, L., Turibula descoperite la Noviodunum-Isaccea, Peuce SN 12, 99-114.

\section{SHEPARD 1965}

Shepard, A. O., Ceramics for the Archaeologist (Washington: Carnegie Institution of Washington - reprint Ann Arbor: Braun-Brumfield, 1985).

\section{SULTOV 1985}

Sultov, B., Ceramic production on the territory of Nicopolis ad Istrum (II ${ }^{\text {nd }}-I V^{\text {th }}$ century) (Sofia: Terra Antiqua Balcanica).

\section{TEODOR 2000}

Teodor, E. S., The COMPASS Method for the estimation of the Capacity of Pottery. In: Lockyear, K./Sly, T. J. T./MihăilescuBârliba, V. (eds.), Computer applications and quantitive methodsinarchaeology. Proceedings of the 24th CAA, Iasi1996. BAR international series, 845 (Oxford: Archaeopress), 25-27.

\section{TEODOR 2015}

Teodor, E. S., The Invisible Giant: Limes Transalutanus. An overview south of Argeş River (Târgovişte: Cetatea de Scaun).

TEODOR 2016

Teodor, E. S., New Archaeological Researches at the Roman Fort from Băneasa (Teleorman County), Cercetări Arheologice 23, 107-126.

\section{TEODOR 2018}

Teodor, E.S., Mapping the change in the Romanian Plain along the Ist millenium. In: Aparaschivei, D./Bilavschi, G. (eds.), Studia romana et mediaevalia europaensia, (BucureștiBrăila: Editura Academiei-Istros), 431-466.

\section{TEODOR/BĂDESCU/HAITĂ 2015}

Teodor, E. S./Bădescu, A./Haită, C., One Hundred Sherds. Chilia-Militari Culture reloaded. Alexandria pottery case, Journal of Ancient History and Archaeology 2/4, 90-135. DOI: $10.14795 /$ j.v2i4.145.

\section{TEODOR/ŞTEFAN 2014}

Teodor, E.S./Ştefan, M., Landscape Archaeology along Limes Transalutanus, Journal of Ancient History and Archaeology 1/3, 31-43. DOI: 10.14795/j.v1i3.68.

TEODOR/ŞTEFAN/BĂDESCU 2017

Teodor, E.S./Ștefan, M./Bădescu, A., Systematic Field Survey on Limes Transalutanus. Săpata Case, Journal of Ancient History and Archaeology 4/2, 51-76. DOI: 10.14795/j. v4i2.261.

\section{TEODORESCU 1964}

Teodorescu, V., Despre cultura Ipotești-Cîndești în lumina cercetărilor arheologice din nord-estul Munteniei (regiunea Ploiești), Studii și Cercetări de Istorie Veche 15/4, 485-503.

\section{WAAGE 1939}

Waage, F. O., Sigillata Wares in the Near East: a List of Potters Stamps by J. H. Iliffe, American Journal of Archaeology 43/3, 539-543.

\section{WOODLEY 1911}

Woolley, C. L., Some Potters's Marks from Cales, The Journal of Roman Studies 1, 199-205. 


\section{LIST OF ANNEXES}

1. Short descriptions (for fabrication, colour, rim and base morphology, decoration and handles) and their codes, as they are used in the other annexes.

2. Bilingual table of the main pottery shapes.

3. Illustrated typology.

4. Relationships between types, fabrication and colours for jars.

5. Jars' typology

6. Jars' essential dimensions

7. Beakers and flagons

8. Open shapes (bowls, dishes, platters)

\section{ANNEX 1}

Short descriptions and codes used in other annexes.

Fabrication

\begin{tabular}{lclc}
\hline descriere (Ro) & cod & description (En) & code \\
\hline grosieră (normal) & G0 & coarse (regular) & $\mathrm{Cr}$ \\
\hline grosieră cu nisip în exces & G1 & coarse (excess of sand) & Csd \\
\hline grosieră cu pietricele & G2 & coarse (excess of silica) & $\mathrm{Csl}$ \\
\hline grosieră cu mica & GM & coarse (excess of mica) & $\mathrm{Cm}$ \\
\hline & & & \\
\hline fină & $\mathrm{F}$ & fine & $\mathrm{F}$ \\
\hline fină cretoasă & FC & fine, dusty & $\mathrm{Fd}$ \\
\hline fină cu mica & FM & Fine, with mica & $\mathrm{Fm}$ \\
\hline fină nisipoasă & FN & Fine but sandy & $\mathrm{Fsd}$ \\
\hline fină cu smalț & F)S & Fine, glazed & $\mathrm{G}$ \\
\hline & & & \\
\hline caolin (FIN) & $\mathrm{C}$ & kaolin, fine & $\mathrm{Kf}$ \\
\hline caolin grosier & $\mathrm{CG}$ & kaolin, coarse & $\mathrm{Kc}$ \\
\hline & & & \\
\hline info absentă & A & no data & $\mathrm{X}$ \\
\hline
\end{tabular}

ANNEX 1. COLOUR

\begin{tabular}{lllc}
\hline cenușiu deschis & $\mathrm{CA}$ & light grey & $\mathrm{IG}$ \\
\hline cenușiu mediu & $\mathrm{CM}$ & middle grey & $\mathrm{mG}$ \\
\hline cenușiu închis & $\mathrm{CZ}$ & dark grey & $\mathrm{dG}$ \\
\hline cenușiu-gălbui & $\mathrm{CG}$ & yellowish grey & $\mathrm{yG}$ \\
\hline brun-cafeniu (deschis) & $\mathrm{BA}$ & light brown & $\mathrm{IB}$ \\
\hline brun-castaniu (mediu) & $\mathrm{BB}$ & middle brown & $\mathrm{mB}$ \\
\hline brun (închis) & $\mathrm{BZ}$ & dark brown & $\mathrm{dB}$ \\
\hline brun & $\mathrm{B}$ & (just) brown & $\mathrm{B}$ \\
\hline albicios & $\mathrm{A}$ & whitish & $\mathrm{W}$ \\
\hline gălbui & $\mathrm{G}$ & yellowish & $\mathrm{Y}$ \\
\hline gălbui-cenușiu & $\mathrm{GC}$ & greyish yellow & $\mathrm{gY}$ \\
\hline roz & $\mathrm{RZ}$ & pink/light/ & $\mathrm{P}$ \\
\hline roşu deschis & $\mathrm{RD}$ & light red & $\mathrm{IR}$ \\
\hline roșu-gălbui & $\mathrm{RG}$ & yellowish red & $\mathrm{yR}$ \\
\hline roșu-portocaliu & $\mathrm{RP}$ & orange-red & $\mathrm{OR}$ \\
\hline & & &
\end{tabular}

\begin{tabular}{lllc}
\hline roșu & RR & red & $\mathrm{R}$ \\
\hline roșu cărămiziu & $\mathrm{RC}$ & brick red & $\mathrm{bR}$ \\
\hline (roşu-închis - v. brun) & & dark red - see brown & \\
\hline (roşu-brun - v. brun) & & brown red - see brown & \\
\hline (cărămiziu-deschis - v. roşu) & & light brick red - see red & \\
\hline cărămiziu & RM & brick like (darker) & $\mathrm{dR}$ \\
\hline glazură oliv & $\mathrm{O}$ & Olive (glaze) & $\mathrm{O}$ \\
\hline necunoscut & $\mathrm{X}$ & unknown & $\mathrm{X}$ \\
\hline cu angobă & $* \&$ & $\begin{array}{l}\text { with slip having the } \\
\text { shade... }\end{array}$ & $*$ \\
\hline cu glazură & $* /$ & $\begin{array}{l}\text { with glaze having the } \\
\text { shade... }\end{array}$ & $*$ \\
\hline
\end{tabular}

\section{ANNEX 1. RIM'S MORPHOLOGY IS EVALUATED ON 4 CLASSES:}

$\begin{array}{ll}\text { null } & 0 \\ \text { small } & 1 \\ \text { balanced } & 2 \\ \text { great } & 3\end{array}$

for each of the next:

total height of the rim

total height of the lip

bent of the rim

comes up a classification having the form '223' ('a middle high rim and lip, strongly bent')

\section{ANNEX 1. LIP (RIM) MORPHOLOGY}

\begin{tabular}{lclc}
\hline Romanian & cod & English & code \\
\hline simplă & D & plain, rounded & R \\
\hline îngroșată & A & thickened outside & T \\
\hline îngroş. dublă & A+ & thickened bilateral & T2 \\
\hline S & B & S shaped section & S \\
\hline plată (orizontală) & C & flat, horizontal & F \\
\hline plată (înclinaţie internă) & C- & flat, tilt inside & F- \\
\hline plată (înclinaţie externă) & C+ & Flat, tilt outside & F+ \\
\hline alta & E & any other & Y \\
\hline acolada externă & L & external accolade & A \\
\hline plan treflat & T & beaked & B \\
\hline lipsă info & X & no data & $\mathbf{X}$ \\
\hline
\end{tabular}

ANNEX 1. BASE MORPHOLOGY IS EXPRESSED BY TWO SETS OF DATA:

\begin{tabular}{lclc}
\hline the side panel & code & base type & code \\
\hline no foot & 1 & flat base & $\mathrm{a}$ \\
\hline simple foot & 2 & concave base & $\mathrm{b}$ \\
\hline profiled foot & 3 & standing on ring & $\mathrm{c}$ \\
\hline
\end{tabular}


ANNEX 1. HANDLES

ATTACHMENT SPOT (BOTH WILL BE MENTIONED, BEGINNING WITH THE LOWER)

\begin{tabular}{llc}
\hline Romanian & English & Code \\
\hline sub diametrul median & below the middle diameter & A \\
\hline diametrul median & on the middle diameter & B \\
\hline peste diametrul median & above the middle diameter & C \\
\hline umăr & on shoulder & D \\
\hline diametrul minim al gâtului & neck diameter & E \\
\hline buză & rim/lip & $\mathrm{F}$ \\
\hline undeva mai sus & somewhere upper than & + \\
\hline undeva mai jos & somewhere lower than & - \\
\hline supra-angular $\left(>90^{\circ}\right)$ & wide bent $\left(>90^{\circ}\right)$ & ${ }^{*}>$ \\
\hline sub-angular $\left(<90^{\circ}\right)$ & sharp bent $\left(<90^{\circ}\right)$ & ${ }^{*}<$ \\
\hline
\end{tabular}

ANNEX 1. HANDLES, CONTINUATION. DIRECTION FROM THE LOWER ATTACHMENT POINT

\begin{tabular}{lll}
\hline Romanian & English & Code \\
\hline $\begin{array}{l}\text { externă (mânerul se } \\
\text { depărtează de axa de }\end{array}$ & $\begin{array}{l}\text { external (the handle } \\
\text { simetrie, sau este paralel) }\end{array}$ & symmerging the axe of \\
\hline $\begin{array}{l}\text { internă (mânerul se } \\
\text { apropie de axa de simetrie) }\end{array}$ & internal (the handle is con- \\
\hline
\end{tabular}

ANNEX 1. HANDLES, CONTINUATION. THE BENT OF THE HANDLE IS

\begin{tabular}{llc}
\hline Romanian & English & Code \\
\hline arcuită simplu & simple arched & 1 \\
\hline supra-arcuită & super-arched (above the attachment spot) & 2 \\
\hline angulară & (more or less) angular & 3 \\
\hline
\end{tabular}

ANNEX 1. HANDLES, CONTINUATION. HANDLE'S SECTION:

\begin{tabular}{llc}
\hline Romanian & English & Code \\
\hline elipsoidală & elipse & $\mathrm{a}$ \\
\hline cu şanţ(uri) longitudinal(e) & longitudinal grooves & $\mathrm{b}$ \\
\hline plată & flat & $\mathrm{c}$ \\
\hline neprecizat & not known & $\mathrm{x}$ \\
\hline
\end{tabular}

Handles' classification has the general form ' $D F \backslash 2 b$ ', following the order of presentation from above.

\section{ANNEX 1. DECORATION}

\begin{tabular}{|c|c|c|c|}
\hline română & cod & English & Code \\
\hline fără & $f$ & no decoration & $\mathrm{n}$ \\
\hline striat & s (ss = multiple layers) & grooves & g \\
\hline lustru & 1 & polish (oriented) & $\mathrm{p}$ \\
\hline muchii & $\mathrm{m}$ & ridge & rd \\
\hline nervuri & $n$ & rib & $\mathrm{rb}$ \\
\hline praguri & $\mathrm{p}$ & threshold & $\mathrm{t}$ \\
\hline rotița & r & cogwheel & c \\
\hline registre & 'ss' = multiple layers & $\begin{array}{l}\text { repeated = more } \\
\text { than one register }\end{array}$ & gg \\
\hline altceva & a & anything else & e \\
\hline
\end{tabular}


ANNEX 2. BILINGUAL TABLE OF THE MAIN POTTERY SHAPES

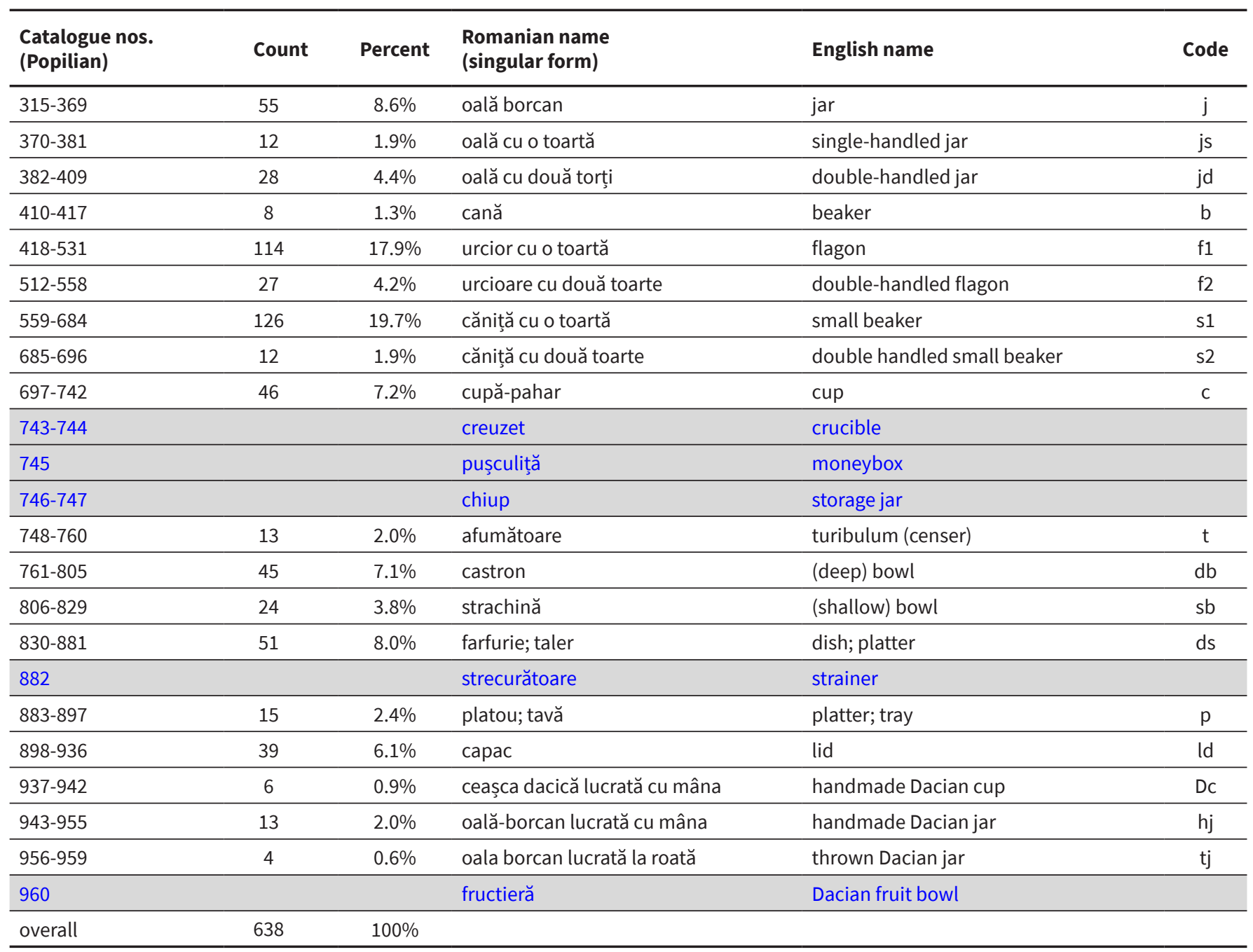

Note that the shaded rows are not discussed in this paper. 


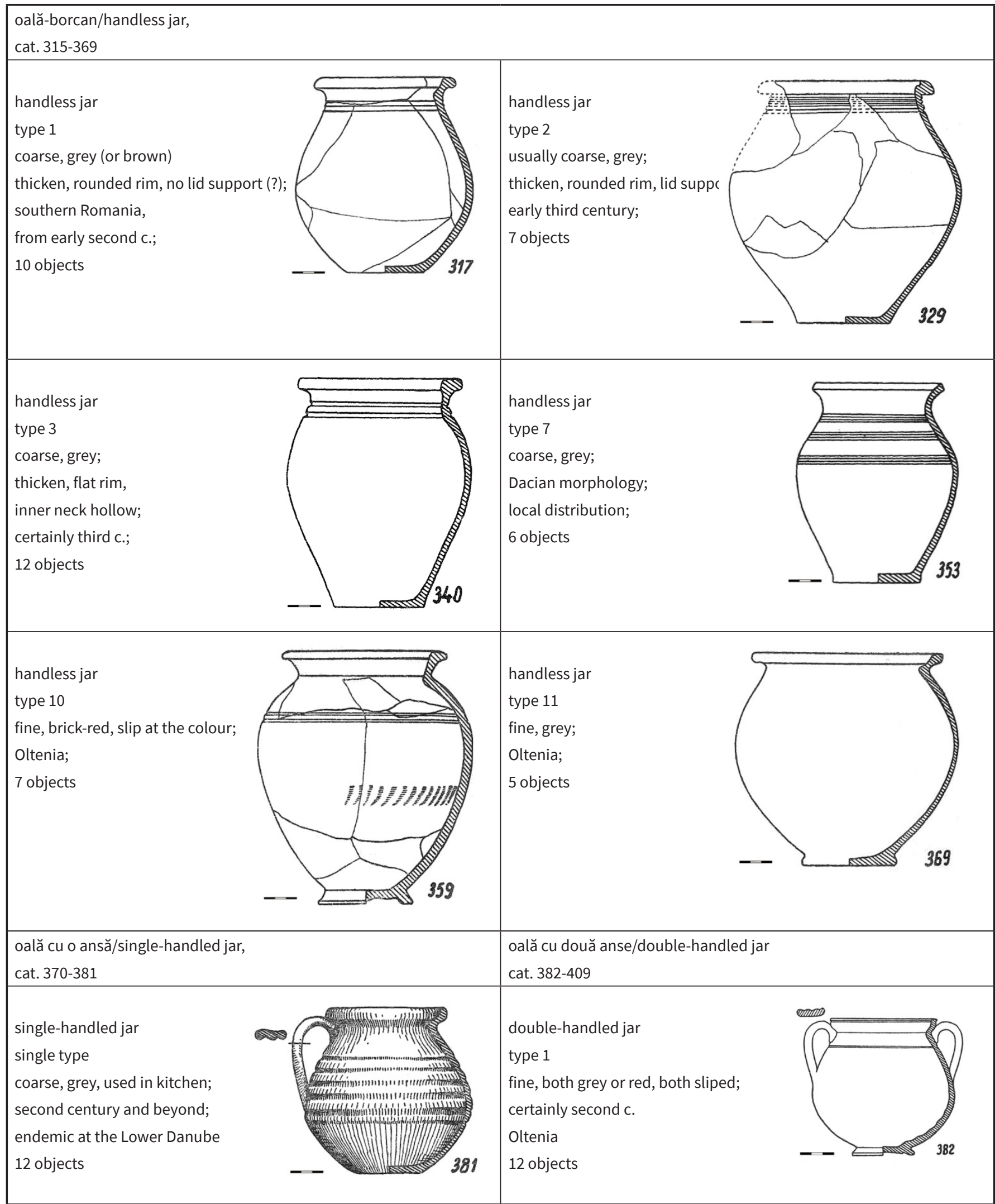


double-handled jar;

type 2

fine, grey or red;

mostly second century,

in military environment;

4 objects

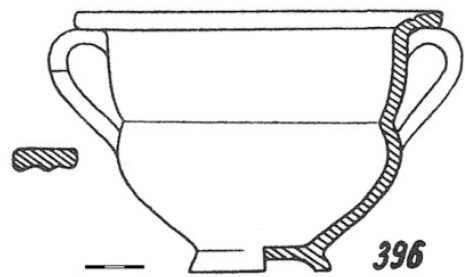

396 double-handled jar; type 4

fine, red, coated;

endemic in Oltenia, known $f$

La Tène origin

8 objects

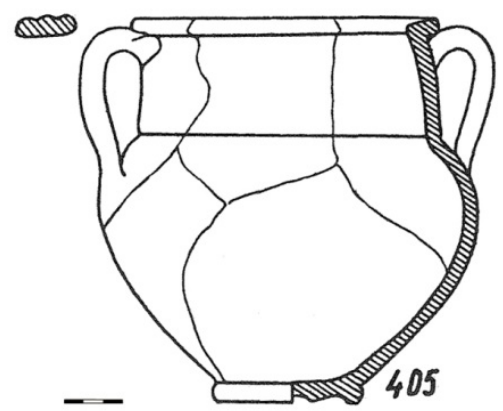

cană/beaker

cat. $410-417$

beaker

type 1

fine, silty, grey, darker slip;

rare

2 objects

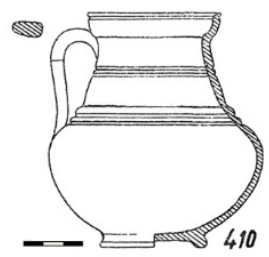

beaker

type 3

fine, red, coated;

frequent all over the Empire;

4 objects

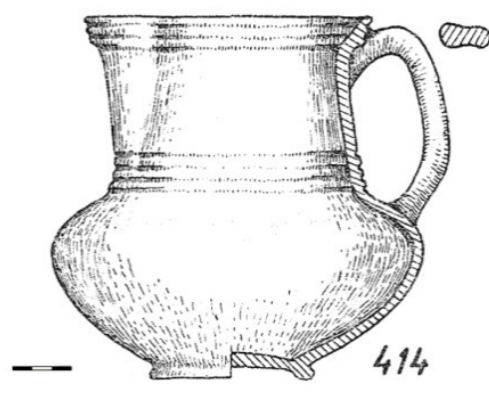

urcior/flagon

cat. $418-531$

flagon

type 1

fine, red, coated

endemic in Lower Danube area

second century

mainly funerary

15 objects

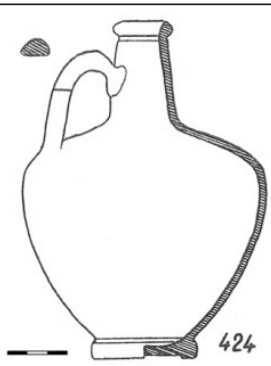

flagon

type 2

fine, usually red, coated

endemic in Middle and

Lower Danube provinces

second half of the second c,

also third c.

30 objects

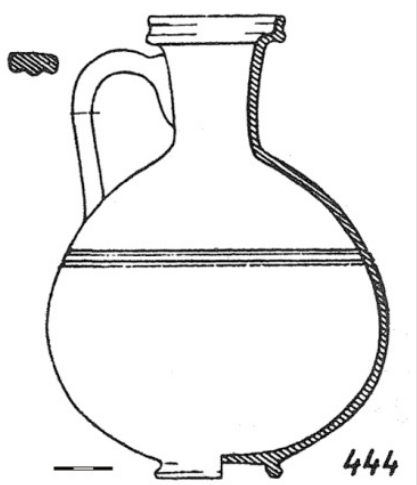

flagon

type 3

fine or slightly sandy, red, coated;

rare, Dacia;

second half of the second c, also third c.

4 objects

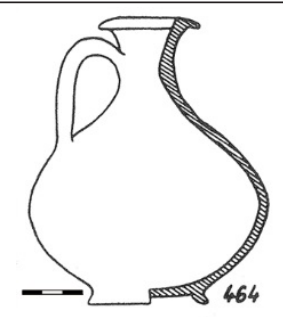

flagon

type 4

fine, yellowish-red;

rare, Oltenia;

middle of the second c.;

mainly funerary

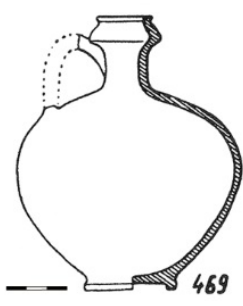

4 objects 


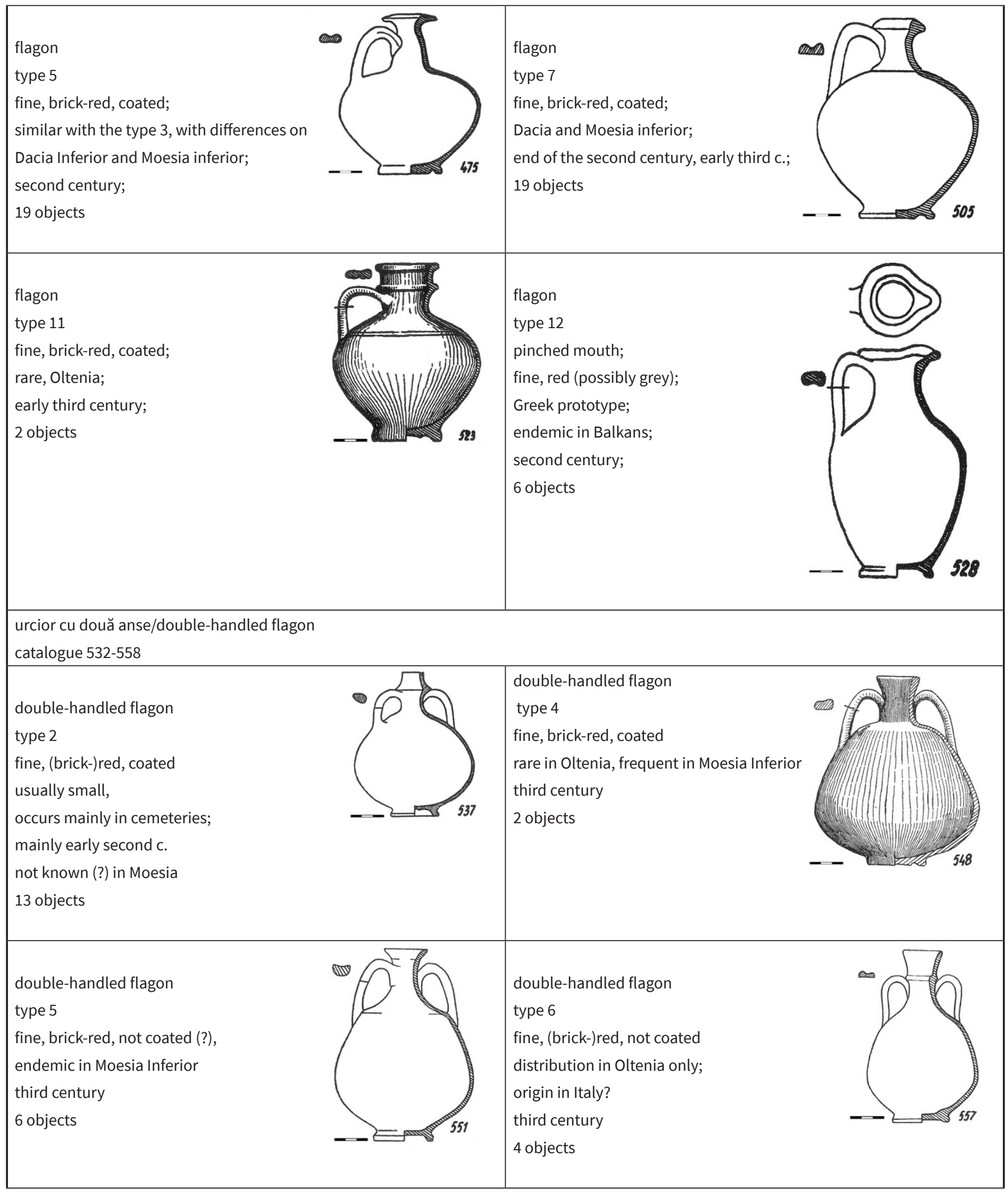




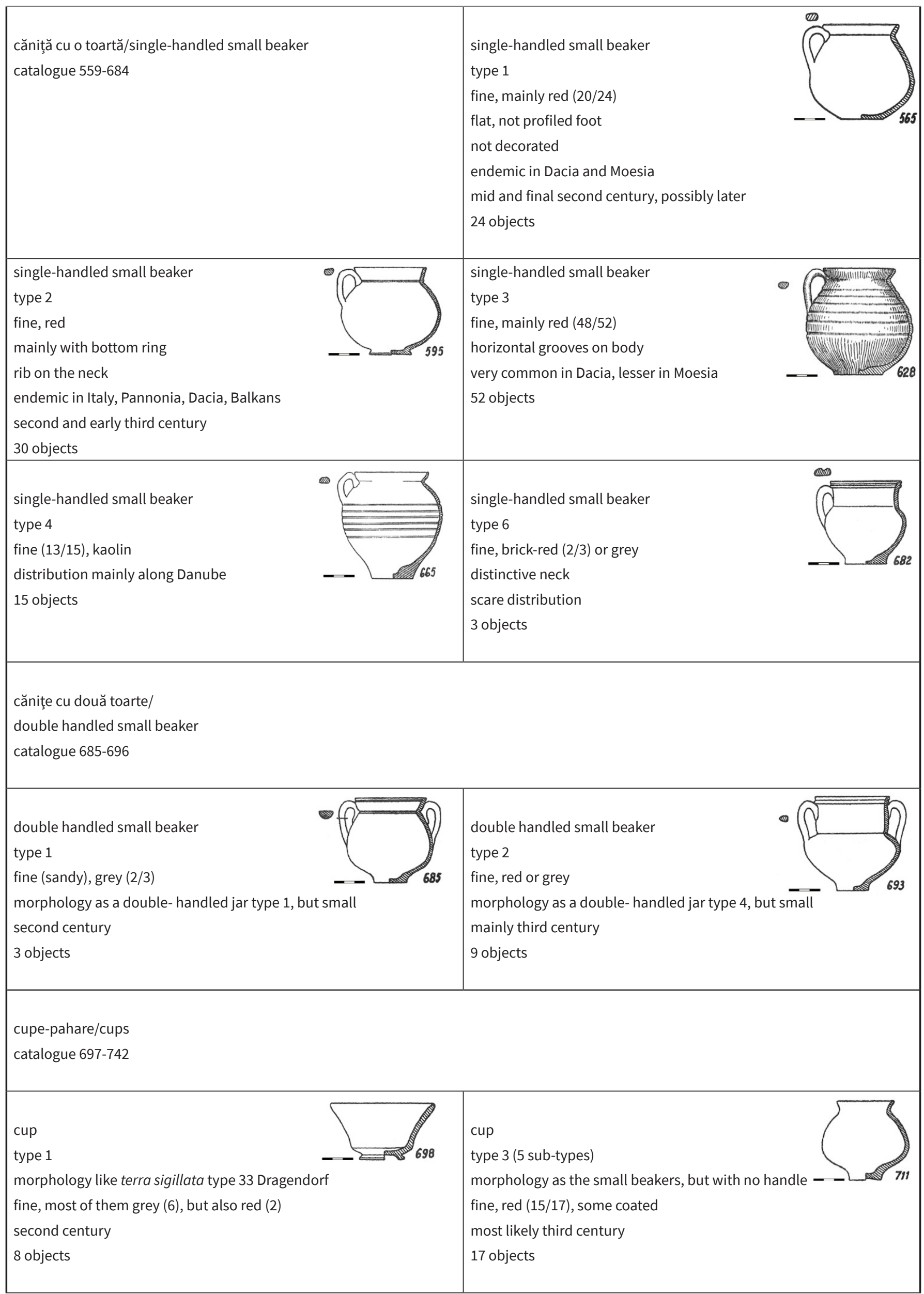




\section{cup}

type 4

fine, (brick-)red, some coated

all over Dacia, second century

6 objects

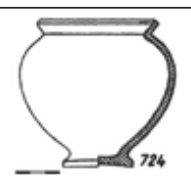

cup

type 5

coarse, brick-red

late second, early third century

3 objects

cup

type 8

usually fine, red, coated

imitating glass production

rare, but all over Dacia

3 objects

censer

type 1

fine, brick-red, coated

second century

4 objects
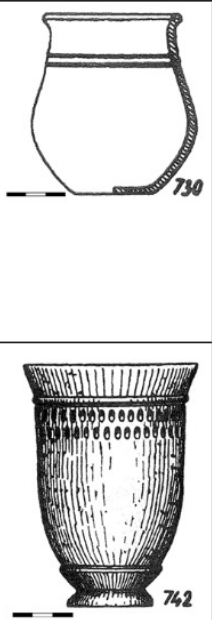

5 objects

afumătoare/

censer (turibulum)

catalogue 748-760

751

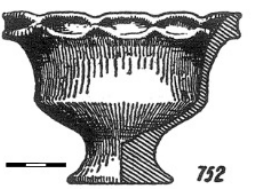

censer

type 4

fine (2), brick-red

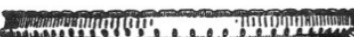

censer

type 2

coarse, brick-red (3)

752

short but profiled foot

4 objects

plain foot, third century

4 objects

castron/

deep bowl

type 1

catalogue 761-805

fine, usually red (9/11), coated;

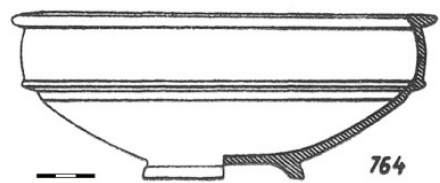

analogies in Panonnia and Dacia Superior (La Tène tradition?)

second half of the second century

11 objects

deep bowl

type 5

coarse, grey (11)

all over Oltenia,

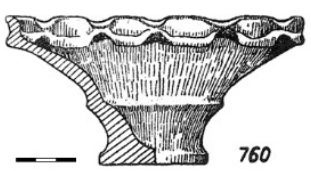

deep bowl

type 2

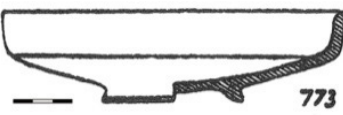

fine, red, coated

analogies Dacia Superior, Moesia Inferior, full chronology

14 objects 


\begin{tabular}{|c|c|}
\hline $\begin{array}{l}\text { deep bowl } \\
\text { type } 6 \\
\text { fine, red (11), no slip } \\
\text { Dacia Sup., Dacia Porolis., late second century and early third century } \\
12 \text { objects }\end{array}$ & $\begin{array}{l}\text { deep bowl } \\
\text { type } 7 \\
\text { fine, red, not coated, } \\
\text { all over Dacia; } \\
\text { unknown chronology } \\
6 \text { objects }\end{array}$ \\
\hline $\begin{array}{l}\text { strachină/shallow bowl } \\
\text { catalogue } 806-829\end{array}$ & $\begin{array}{l}\text { shallow bowl } \\
\text { type } 1 \\
\text { fine, brick-red } \\
\text { apparently absent from Dacia Superior; analogies in Moesia Inferior; } \\
\text { second half of the second century } \\
7 \text { objects }\end{array}$ \\
\hline $\begin{array}{l}\text { shallow bowl } \\
\text { type } 2 \\
\text { fine, brick-red }{ }^{1} \\
\text { second century, all over Dacia, mainly in cemeteries } \\
8 \text { objects }\end{array}$ & $\begin{array}{l}\text { shallow bowl } \\
\text { type } 3 \\
\text { fine, brick-red } \\
\text { similar to deep bowl type } 7 \\
\text { analogies in Moesia Inferior (Hotnitza), late second and early third } \\
\text { century } \\
9 \text { objects }\end{array}$ \\
\hline $\begin{array}{l}\text { farfurie; taler/dish; platter } \\
\text { catalogue } 830-881\end{array}$ & \\
\hline $\begin{array}{l}\text { dish } \\
\text { type } 1 \text { coarse, } \\
\text { grey (6/7), } \\
\text { mainly in military sites, third century }\end{array}$ & $\begin{array}{l}\text { dish } \\
\text { type } 2 \\
\text { fine, brick-red } \\
\text { second century, southern Dacia } \\
5 \text { objects }\end{array}$ \\
\hline $\begin{array}{l}\text { dish, type } 3 \\
\text { coarse, kaolin } \\
\text { late second century (and proba.., } \ldots \ldots, \ldots \ldots, \\
5 \text { objects }\end{array}$ & $\begin{array}{l}\text { dish, type } 5 \\
\text { coarse, grey ( } 7) \text {, } \\
\text { one kaolin } \\
\text { all over Dacia } \\
8 \text { objects }\end{array}$ \\
\hline $\begin{array}{l}\text { dish, type } 6^{2} \\
\text { fine, (brick-)red } \\
\text { all over Dacia } \\
9 \text { objects }\end{array}$ & $\begin{array}{l}\text { dish, type } 7^{3} \\
\text { fine, brick-red (14) } \\
\text { Middle and Lower Danube pı } \\
15 \text { objects }\end{array}$ \\
\hline
\end{tabular}

${ }^{1}$ In his commentaries, Popilian $(1976,122)$ said that this type is always covered by a dark-red (brownish) slip, a fact not confirmed in the catalogue (Popilian 1976, 212), in which only one shallow bowl is slipped (no. 819, just 'red').

${ }^{2}$ Which would copy sigillata type Curle 23 (debatable; v. http://potsherd.net/atlas/types/sigillata/form/CU23) or Ludowici Tb (Oswald, Pryce, 1920, plate LIX/2), as Popilian said (Popilian 1976, 125), both relatively far. More likely Geissner 2, no. 16 (Oswald, Pryce, 1920, plate LIX/9).

${ }^{3}$ Following TS Dragendorf form 35 (Popilian 1976, 125), which is possible (Oswald, Pryce, 1920, plate LIII/19, Niederbieber, middle Rhine, late second century). 


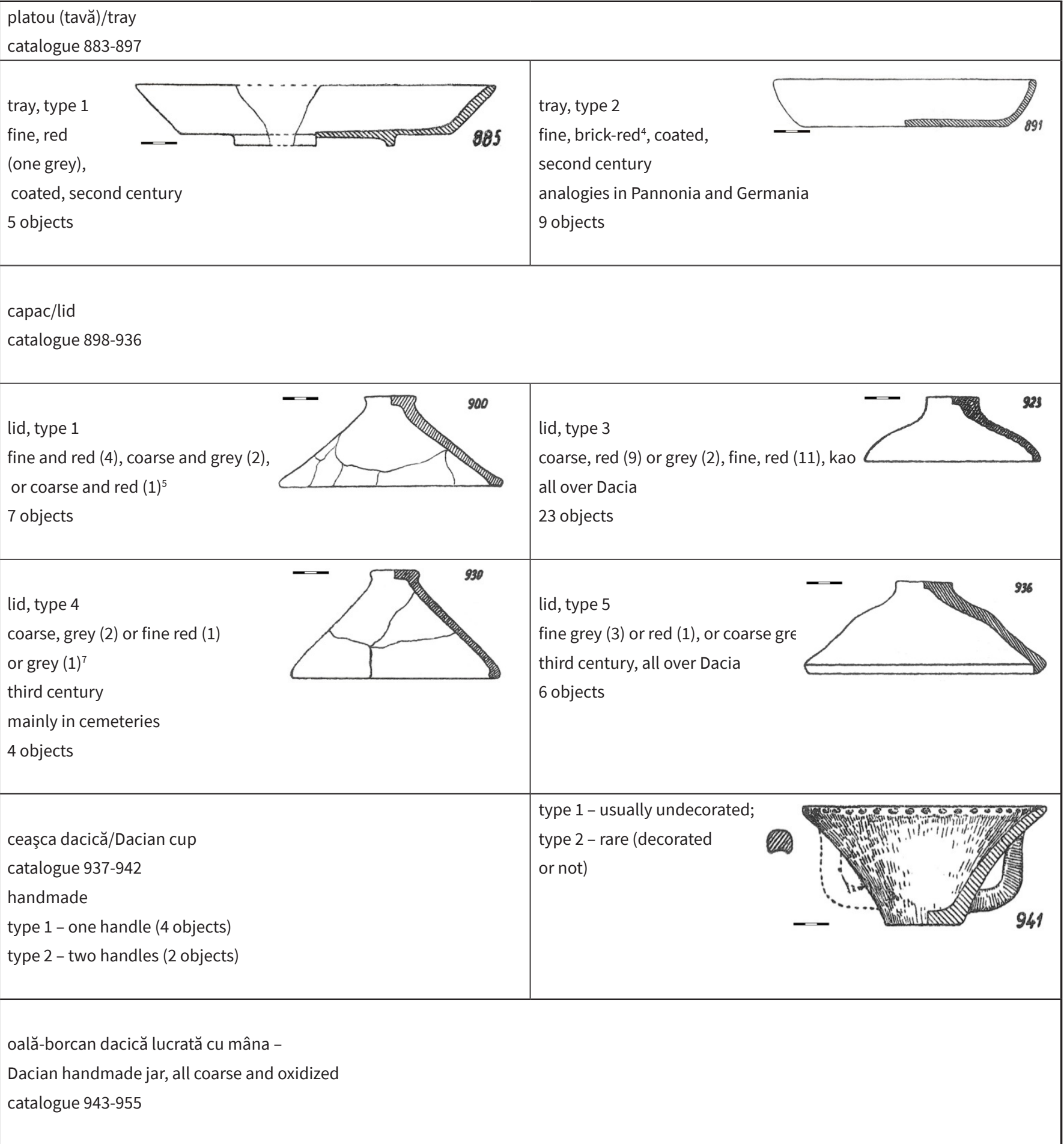

\footnotetext{
${ }^{4}$ In his commentaries, Popilian $(1976,126)$ wrote that they could be red or grey; nevertheless, the catalogue (nos. 888-896) presents exclusively fine, brick-red trays, almost always having a red slip (lighter than the margins?)

${ }^{5}$ General considerations (Popilian 1976, 127-128) do not stand against published data (cat. nos. 898-904).

${ }^{6}$ The diversity of the fabrication types for one and the same morphology is un-paralleled. The reason is plain: the lids were used along different classes of recipients.

${ }^{7}$ The same contradictions between the general description and the data presented in catalogue, as mentioned in the previous note.
} 


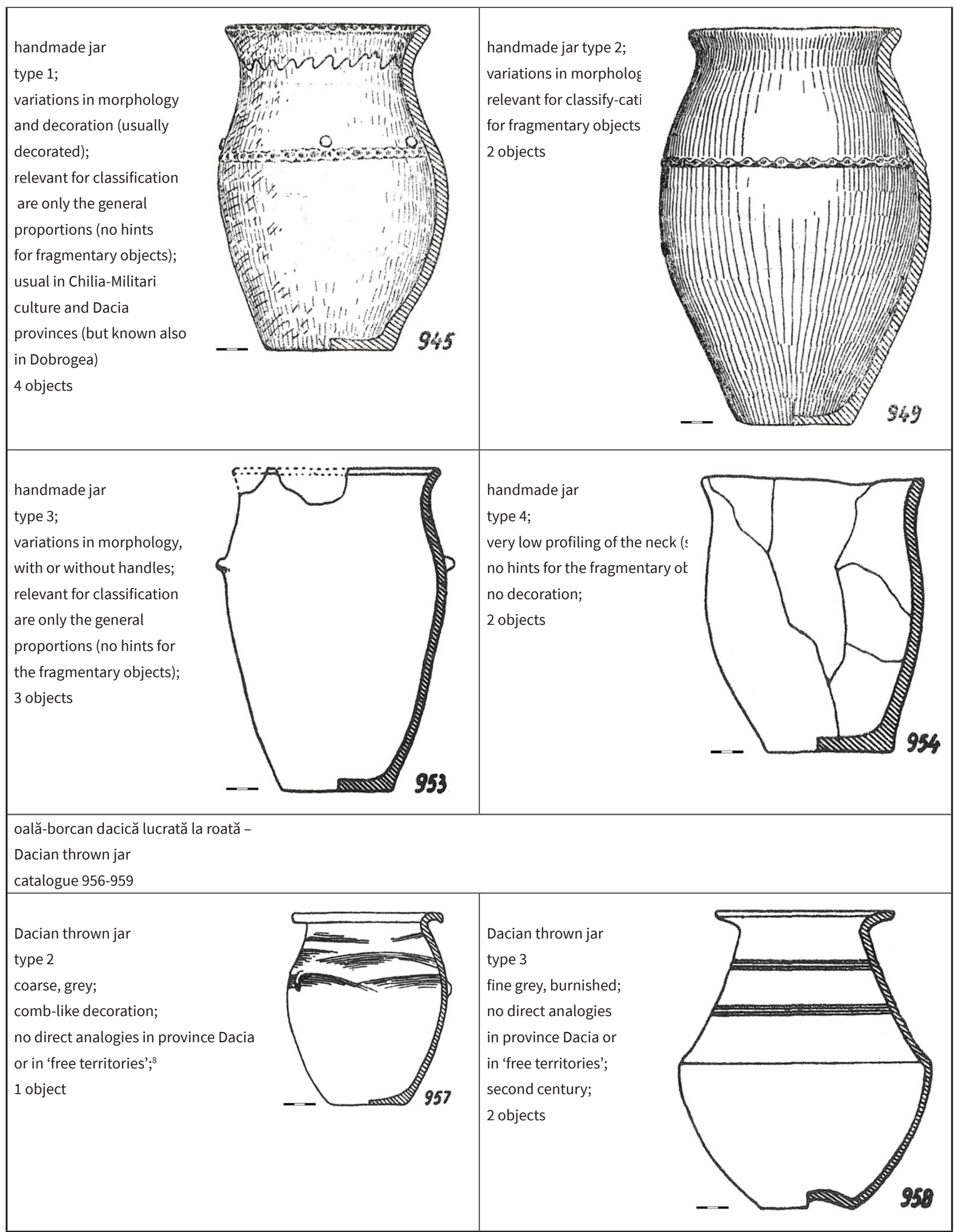

Note that the types made out from a single specimen were skipped.

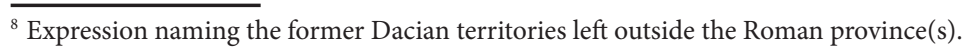


ANNEX 4. RELATIONSHIPS BETWEEN TYPES (COL.1), FABRICATION (COL. 2) AND COLOURS FOR JARS.

For types (and their codes) - see Annex 2; for fabric and colours see Annex 1.

\begin{tabular}{|c|c|c|c|c|c|c|c|c|c|c|c|c|c|c|c|c|c|}
\hline Type & fabric & IG & mG & mG\&dG & dG & yG & w & gY & $\mathrm{mB}$ & bR & $\begin{array}{c}\mathrm{dbR} \\
\& B\end{array}$ & $\begin{array}{c}\mathrm{dbR} \\
\& \mathrm{R}\end{array}$ & $\mathbf{R}$ & $\begin{array}{c}\mathrm{R} \\
\& \mathrm{~B}\end{array}$ & $\begin{array}{c}\text { R\& } \\
\mathrm{dbR}\end{array}$ & $\begin{array}{c}\text { P\& } \\
\mathrm{dbR}\end{array}$ & $x$ \\
\hline j1 & $\mathrm{Cr}$ & & 1 & & 1 & 1 & & 1 & 1 & & & & & & & & \\
\hline j1 & Csd & & & & & & & & 2 & & & & & & & & \\
\hline j1 & Csl & & 1 & & 2 & & & & & & & & & & & & \\
\hline j2 & $\mathbf{F}$ & & 1 & & & & & & & & & & & & & & \\
\hline j2 & $\mathrm{Cr}$ & & & & 2 & & & & & & & & & & & & \\
\hline j2 & Csl & & 1 & & 1 & & & & & & & & & & & & 2 \\
\hline j3 & $\mathrm{Cr}$ & 1 & 1 & & 4 & & & & & & & & & & & & \\
\hline j3 & Csl & 1 & 2 & & 1 & & & & & & & & & & & & 2 \\
\hline j4 & $\mathrm{Cr}$ & & 2 & & & & & & & & & & & & & & \\
\hline j4 & Csd & 1 & & & & & & & & & & & & & & & \\
\hline j5 & $x$ & & & & 1 & & & & & & & & & & & & \\
\hline j5 & Csl & & & & & & & & & & & & & & & & 1 \\
\hline j6 & $\mathrm{Cr}$ & & & & 1 & & & & & & & & & & & & \\
\hline j7 & $\mathrm{Cr}$ & 1 & 4 & & & & & & & & & & & & & & \\
\hline j7 & Csl & & & & & & & & & 1 & & & & & & & \\
\hline j8 & $\mathrm{Cr}$ & & 1 & & & & & & & & & & & & & & \\
\hline j9 & $\mathrm{Cr}$ & & & & 1 & & & & & & & & & & & & \\
\hline j10 & $\mathrm{F}$ & & 2 & & & & & & & 4 & & & 1 & & & & \\
\hline j11 & $\mathrm{F}$ & & 2 & & & & & & & & & & & & & & \\
\hline j11 & $\mathrm{Cr}$ & & 2 & & & & & & & & & & & & & & \\
\hline j11 & G & & & & & & & & & 1 & & & & & & & \\
\hline $\mathrm{j} 1 \mathrm{~h}$ & $\mathrm{Cr}$ & & 12 & & & & & & & & & & & & & & \\
\hline $\mathrm{j} 2 \mathrm{~h} 1$ & $F$ & & 4 & 1 & & & & & & & & & 3 & & & & \\
\hline $\mathrm{j} 2 \mathrm{~h} 1$ & Fsd & & & & & & & & & & & & 1 & & & & \\
\hline j2h1v & $\mathrm{F}$ & & & & & & & & & & & & 3 & & & & \\
\hline $\mathrm{j} 2 \mathrm{~h} 2$ & $\mathrm{~F}$ & & 2 & & & & & & & & & & 1 & & & & \\
\hline $\mathrm{j} 2 \mathrm{~h} 2$ & $\mathrm{Cr}$ & & 1 & & & & & & & & & & & & & & \\
\hline $\mathrm{j} 2 \mathrm{~h} 3$ & $\mathrm{Cr}$ & & & & & & & & & & & & & & 1 & & \\
\hline $\mathrm{j} 2 \mathrm{~h} 4$ & $\mathrm{~F}$ & & & & & & & & & & & 1 & 3 & 1 & 2 & 1 & \\
\hline $\mathrm{j} 2 \mathrm{~h} 4 \mathrm{v}$ & $\mathbf{F}$ & & & & & & & & & & 1 & & & & & & \\
\hline j2h5 & $F ?$ & & & & & & 1 & & & & & & & & & & 1 \\
\hline $\mathrm{j} 2 \mathrm{~h} 6$ & $\mathbf{F}$ & & & & & & & & & & & & & & 1 & & \\
\hline
\end{tabular}


ANNEX 5. JARS' TYPOLOGY

Handless jars

\begin{tabular}{|c|c|c|c|c|c|c|c|}
\hline catalogue & type & fabrication & colour & rim & lip & base & decoration \\
\hline 315 & j1 & Csd & B & 321 & S & $3 a$ & g \\
\hline 316 & $\mathrm{j} 1$ & $\mathrm{Cr}$ & $\mathrm{mG}$ & 222 & $S$ & $1 a$ & g \\
\hline 317 & j1 & $\mathrm{Cr}$ & $\mathrm{dG}$ & 122 & $\mathrm{~F}$ & $1 a$ & g \\
\hline 318 & j1 & Csl & $\mathrm{mG}$ & 122 & $\mathrm{~F}$ & $1 c$ & g \\
\hline 319 & j1 & Csl & $\mathrm{dG}$ & 222 & $\mathrm{~F}$ & $2 b$ & g \\
\hline 320 & j1 & Csl & $\mathrm{dG}$ & 222 & $\mathrm{~F}$ & $1 a$ & g \\
\hline 321 & j1 & $\mathrm{Cr}$ & $y G$ & 321 & S & $1 a$ & g \\
\hline 322 & j1 & $\mathrm{Cr}$ & gY & 321 & $S$ & $1 a$ & g \\
\hline 323 & j1 & $\mathrm{Cr}$ & B & 221 & $S$ & $1 a$ & g \\
\hline 324 & j1 & Csd & B & 222 & $x$ & $2 a$ & g \\
\hline 325 & j2 & Csl & $x$ & 223 & $\mathrm{~F}$ & $2 a$ & g \\
\hline 326 & j2 & Csl & $\mathrm{dG}$ & 123 & $\mathrm{~F}$ & $2 b$ & g \\
\hline 327 & j2 & $\mathrm{Cr}$ & $\mathrm{dG}$ & 123 & $\mathrm{~F}$ & $3 c$ & g \\
\hline 328 & j2 & Csl & $m G$ & 112 & $S$ & $2 b$ & g \\
\hline 329 & j2 & $\mathrm{F}$ & $m G$ & 112 & $\mathrm{~F}$ & $2 a$ & $\mathrm{~g}$ \\
\hline 330 & j2 & Csl & $x$ & 112 & $\mathrm{~F}$ & $2 b$ & g \\
\hline 331 & j2 & $\mathrm{Cr}$ & $\mathrm{dG}$ & 112 & $\mathrm{~F}$ & $2 a$ & g \\
\hline 332 & j3 & $\mathrm{Cr}$ & $\mathrm{dG}$ & 212 & $R$ & $2 a$ & g \\
\hline 333 & j3 & $\mathrm{Cr}$ & IG & 122 & $\mathrm{~F}$ & $3 a$ & g \\
\hline 334 & j3 & $\mathrm{Cr}$ & $\mathrm{dG}$ & 222 & $\mathrm{~F}$ & $2 a$ & $n$ \\
\hline 335 & j3 & Csl & $\mathrm{dG}$ & 222 & B & $1 \mathrm{~b}$ & g \\
\hline 336 & j3 & $\mathrm{Cr}$ & $\mathrm{dG}$ & 322 & B & $1 a$ & g \\
\hline 337 & j3 & $\mathrm{Cr}$ & $\mathrm{dG}$ & 212 & B & $1 \mathrm{~b}$ & g \\
\hline 338 & j3 & $\mathrm{Cr}$ & $\mathrm{mG}$ & 121 & $B$ & $1 a$ & $\mathrm{n}$ \\
\hline 339 & j3 & Csl & & & & & g \\
\hline 340 & j3 & Csl & $\mathrm{mG}$ & 222 & $S$ & $1 a$ & g \\
\hline 341 & j3 & Csl & IG & 223 & $\mathrm{~F}$ & $2 a$ & $\mathrm{~g}$ \\
\hline 342 & j3 & Csl & $\mathrm{mG}$ & 121 & $S$ & $2 a$ & g \\
\hline 343 & j3 & Csl & $x$ & 122 & $\mathrm{~F}$ & $1 \mathrm{c}$ & g \\
\hline 344 & j4 & Csd & IG & 222 & $S$ & $1 a$ & $\mathrm{n}$ \\
\hline 345 & j4 & $\mathrm{Cr}$ & $\mathrm{mG}$ & 122 & $S$ & $1 a$ & g \\
\hline 346 & j4 & $\mathrm{Cr}$ & $\mathrm{mG}$ & 132 & $\mathrm{~F}$ & $1 a$ & g \\
\hline 347 & j5 & Csl & $x$ & 232 & B & $2 b$ & gc \\
\hline 348 & j5 & $x$ & $\mathrm{dG}$ & & & & \\
\hline 349 & j6 & $\mathrm{Cr}$ & $\mathrm{dG}$ & 132 & $\mathrm{R}$ & $1 a$ & g \\
\hline 350 & j7 & $\mathrm{Cr}$ & IG & 111 & $\mathrm{Y}$ & $3 c$ & $\mathrm{n}$ \\
\hline 351 & j7 & $\mathrm{Cr}$ & $\mathrm{mG}$ & 331 & B & $3 a$ & g \\
\hline 352 & j7 & Csl & bR & 321 & B & $1 a$ & gg \\
\hline 353 & j7 & $\mathrm{Cr}$ & $\mathrm{mG}$ & 332 & B & $2 a$ & gg \\
\hline 354 & j7 & $\mathrm{Cr}$ & $\mathrm{mG}$ & 232 & B & $2 a$ & $n$ \\
\hline 355 & j7 & $\mathrm{Cr}$ & $\mathrm{mG}$ & 122 & B & $2 a$ & $\mathrm{n}$ \\
\hline 356 & j8 & $\mathrm{Cr}$ & $\mathrm{mG}$ & 121 & $S$ & $2 a$ & $\mathrm{~g}$ \\
\hline 357 & j9 & $\mathrm{Cr}$ & $\mathrm{dG}$ & 122 & B & $2 a$ & $\mathrm{CCC}$ \\
\hline 358 & j10 & $\mathrm{F}$ & $\mathrm{mG}$ & 212 & $R$ & $3 c$ & g \\
\hline
\end{tabular}




\begin{tabular}{cccccccc}
\hline catalogue & type & fabrication & colour & rim & lip & base & decoration \\
\hline 359 & $\mathrm{j} 10$ & $\mathrm{~F}$ & $\mathrm{mG}$ & 233 & $\mathrm{~S}$ & $3 \mathrm{c}$ & $\mathrm{gp}$ \\
\hline 360 & $\mathrm{j} 10$ & $\mathrm{~F}$ & $\mathrm{bR}$ & 233 & $\mathrm{~B}$ & $3 \mathrm{~b}$ & $\mathrm{rbg}$ \\
\hline 361 & $\mathrm{j} 10$ & $\mathrm{~F}$ & $\mathrm{R}$ & 232 & $\mathrm{X}$ & $3 \mathrm{~b}$ & $\mathrm{~g}$ \\
\hline 362 & $\mathrm{j10}$ & $\mathrm{F}$ & $\mathrm{bR}$ & 223 & $\mathrm{~B}$ & $2 \mathrm{c}$ & $\mathrm{n}$ \\
\hline 363 & $\mathrm{j} 10$ & $\mathrm{~F}$ & $\mathrm{bR}$ & 223 & $\mathrm{~B}$ & $2 \mathrm{c}$ & $\mathrm{g}$ \\
\hline 364 & $\mathrm{j10}$ & $\mathrm{F}$ & $\mathrm{bR}$ & 123 & $\mathrm{~S}$ & $\mathrm{2c}$ & $\mathrm{n}$ \\
\hline 365 & $\mathrm{j} 11$ & $\mathrm{~F}$ & $\mathrm{mG}$ & 133 & $\mathrm{~B}$ & $3 \mathrm{c}$ & $\mathrm{n}$ \\
\hline 366 & $\mathrm{j} 11$ & $\mathrm{~F}$ & $\mathrm{mG}$ & 133 & $\mathrm{~B}$ & $3 \mathrm{c}$ & $\mathrm{g}$ \\
\hline 367 & $\mathrm{j} 11$ & $\mathrm{G}$ & $\mathrm{bR}$ & 222 & $\mathrm{~B}$ & $3 \mathrm{a}$ & $\mathrm{n}$ \\
\hline 368 & $\mathrm{j} 11$ & $\mathrm{Cr}$ & $\mathrm{mG}$ & 123 & $\mathrm{~B}$ & $\mathrm{1a}$ & $\mathrm{n}$ \\
\hline 369 & $\mathrm{j} 11$ & $\mathrm{Cr}$ & $\mathrm{mG}$ & 123 & $\mathrm{~F}$ & $3 \mathrm{a}$ & $\mathrm{n}$ \\
\hline
\end{tabular}

ANNEX 5. JARS' TYPOLOGY, CONTINUATION

simple handled jars

\begin{tabular}{cccccccc}
\hline catalogue & type & fabrication & colour & rim & lip & base & decoration \\
\hline 370 & $\mathrm{j} 1$ & $\mathbf{C r}$ & $\mathbf{m G}$ & 122 & $\mathbf{F}$ & 1b & $\mathbf{g}$ \\
\hline 371 & $\mathrm{j} 1$ & $\mathbf{C r}$ & $\mathbf{m G}$ & 122 & $\mathbf{F}$ & $1 \mathrm{a}$ & $\mathbf{g}$ \\
\hline 372 & $\mathrm{j} 1$ & $\mathbf{C r}$ & $\mathbf{m G}$ & 122 & $\mathbf{F}$ & $1 \mathrm{a}$ & $\mathbf{g}$ \\
\hline 373 & $\mathrm{j} 1$ & $\mathbf{C r}$ & $\mathbf{m G}$ & 122 & $\mathbf{F}$ & $1 \mathrm{a}$ & $\mathbf{g}$ \\
\hline 374 & $\mathrm{j} 1$ & $\mathbf{C r}$ & $\mathbf{m G}$ & 122 & $\mathbf{F}$ & $1 \mathrm{a}$ & $\mathbf{g}$ \\
\hline 375 & $\mathrm{j} 1$ & $\mathbf{C r}$ & $\mathbf{m G}$ & 122 & $\mathbf{F}$ & $1 \mathrm{a}$ & $\mathbf{g}$ \\
\hline 376 & $\mathrm{j} 1$ & $\mathbf{C r}$ & $\mathbf{m G}$ & 122 & $\mathbf{F}$ & $1 \mathrm{a}$ & $\mathbf{g}$ \\
\hline 377 & $\mathrm{j} 1$ & $\mathbf{C r}$ & $\mathbf{m G}$ & 122 & $\mathbf{F}$ & $1 \mathrm{a}$ & $\mathbf{g}$ \\
\hline 378 & $\mathrm{j} 1$ & $\mathbf{C r}$ & $\mathbf{m G}$ & 122 & $\mathbf{F}$ & $2 \mathrm{a}$ & $\mathbf{g}$ \\
\hline 379 & $\mathrm{j} 1$ & $\mathbf{C r}$ & $\mathbf{m G}$ & 122 & $\mathbf{F}$ & $1 \mathrm{a}$ & $\mathbf{g}$ \\
\hline 380 & $\mathrm{j} 1$ & $\mathbf{C r}$ & $\mathbf{m G}$ & 122 & $\mathbf{F}$ & $2 \mathrm{a}$ & $\mathbf{g}$ \\
\hline 381 & $\mathrm{j} 1$ & $\mathbf{C r}$ & $\mathbf{m G}$ & 122 & $\mathbf{F}$ & $1 \mathrm{a}$ & $\mathbf{g}$ \\
\hline
\end{tabular}

ANNEX 5. JARS' TYPOLOGY, CONTINUATION

double handled jars

\begin{tabular}{|c|c|c|c|c|c|c|c|}
\hline catalogue & type & fabrication & colour & rim & lip & base & decoration \\
\hline 382 & j2_1 & $\mathrm{FN}$ & $\mathbf{R}$ & 122 & $\mathbf{F}$ & $3 c$ & g \\
\hline 383 & j2_1 & $\mathbf{F}$ & mG\&dG & 122 & $\mathbf{F}$ & $3 c$ & g \\
\hline 384 & j2_1 & $\mathbf{F}$ & mG & 222 & $\mathbf{F}$ & $3 c$ & g \\
\hline 385 & j2_1 & $\mathbf{F}$ & mG & 222 & $\mathbf{F}$ & $3 c$ & g \\
\hline 386 & j2_1 & $\mathbf{F}$ & $\mathbf{R}$ & 222 & $\mathbf{F}$ & $2 b$ & g \\
\hline 387 & j2_1 & $\mathbf{F}$ & mG & 222 & $\mathbf{F}$ & $3 c$ & g \\
\hline 388 & j2_1 & $\mathbf{F}$ & mG & 122 & $\mathbf{F}$ & $3 c$ & $\mathbf{n}$ \\
\hline 389 & j2_1 & $\mathbf{F}$ & $\mathbf{R}$ & 122 & $\mathbf{F}$ & $3 c$ & g \\
\hline 390 & j2_1 & $\mathbf{F}$ & $\mathbf{R}$ & 222 & $\mathbf{F}$ & $3 c$ & gg \\
\hline 391 & j2_1v & $\mathbf{F}$ & $\mathbf{R}$ & 122 & $\mathbf{F}$ & $3 c$ & $\mathbf{n}$ \\
\hline 392 & j2_1v & $\mathbf{F}$ & $\mathbf{R}$ & 122 & $\mathbf{F}$ & $3 c$ & $\mathbf{n}$ \\
\hline 393 & j2_1v & $\mathbf{F}$ & $\mathbf{R}$ & 122 & $\mathbf{F}$ & $3 c$ & g \\
\hline 394 & j2_2 & $\mathrm{Cr}$ & mG & 332 & $\mathbf{R}$ & $3 c$ & g \\
\hline 395 & j2_2 & $\mathbf{F}$ & mG & 332 & $\mathbf{R}$ & $3 a$ & $\mathrm{~m}$ \\
\hline
\end{tabular}




\begin{tabular}{|c|c|c|c|c|c|c|c|}
\hline catalogue & type & fabrication & colour & rim & lip & base & decoration \\
\hline 396 & j2_2 & $\mathbf{F}$ & mG & 332 & $\mathbf{R}$ & $3 c$ & $\mathrm{~m}$ \\
\hline 397 & j2_2 & $\mathbf{F}$ & $\mathbf{R}$ & 332 & $\mathbf{R}$ & $3 c$ & $\mathbf{n}$ \\
\hline 398 & j2_3 & $\mathrm{Cr}$ & $\mathrm{R} \& \mathrm{dR}$ & 221 & B & $2 b$ & gg \\
\hline 399 & j2_4 & $\mathbf{F}$ & $\mathrm{R}$ & 321 & $\mathbf{R}$ & $3 c$ & $\mathrm{p}$ \\
\hline 400 & j2_4 & $\mathbf{F}$ & $\mathrm{R}$ & 321 & $\mathbf{R}$ & $3 c$ & $\mathbf{g}$ \\
\hline 401 & j2_4 & $\mathbf{F}$ & $\mathrm{R}$ & 321 & $\mathbf{R}$ & $3 c$ & $\mathbf{g}$ \\
\hline 402 & j2_4 & $\mathbf{F}$ & $\mathrm{P} \& \mathrm{dR}$ & 321 & $\mathbf{R}$ & $2 c$ & $\mathbf{g}$ \\
\hline 403 & j2_4 & $\mathbf{F}$ & $\mathrm{R} \& \mathrm{dR}$ & 321 & $\mathbf{R}$ & $3 c$ & $\mathbf{g}$ \\
\hline 404 & j2_4 & $\mathbf{F}$ & $\mathrm{R} \& \mathrm{dR}$ & 321 & $\mathbf{R}$ & $3 c$ & $\mathrm{p}$ \\
\hline 405 & j2_4 & $\mathbf{F}$ & $\mathrm{dR \& R}$ & 321 & $\mathbf{R}$ & $3 c$ & $\mathrm{p}$ \\
\hline 406 & j2_4 & $\mathbf{F}$ & $R \& B$ & 321 & $\mathbf{R}$ & $2 a$ & $\mathrm{p}$ \\
\hline 407 & j2_4v & $\mathbf{F}$ & $\mathrm{dR} \& \mathbf{B}$ & 311 & & $3 c$ & g \\
\hline 408 & j2_5 & $F ?$ & $x$ & 122 & & $3 c$ & gg \\
\hline 409 & j2_6 & $\mathbf{F}$ & $\mathrm{R} \& \mathrm{dR}$ & 312 & & $3 c$ & gg \\
\hline
\end{tabular}

ANNEX 6. JARS' ESSENTIAL DIMENSIONS

handless jars ( $\mathrm{j}$ class), as rendered by the Compass technology

\begin{tabular}{ccccccccc}
\hline Type & Count & $\begin{array}{c}\text { Capacity } \\
\text { average }(\mathbf{l})\end{array}$ & $\begin{array}{c}\text { Min. of } \\
\text { capacity }\end{array}$ & $\begin{array}{c}\text { Max. of } \\
\text { capacity }\end{array}$ & $\begin{array}{c}\text { Height } \\
\text { average }(\mathbf{c m})\end{array}$ & $\begin{array}{c}\text { Min. of } \\
\text { height }\end{array}$ & $\begin{array}{c}\text { Max. of } \\
\text { height }\end{array}$ \\
\hline$j 1$ & 10 & 1.35 & 0.30 & 2.60 & 15.20 & 9.06 & 20.13 \\
\hline$j 2$ & 7 & 3.76 & 1.57 & 6.73 & 21.33 & 16.02 & 26.45 \\
\hline$j 3$ & 11 & 2.95 & 0.84 & 8.21 & 20.93 & 13.24 & 35.28 \\
\hline$j 4$ & 3 & 2.71 & 1.83 & 3.81 & 20.92 & 17.59 & 23.97 \\
\hline$j 5$ & 1 & 3.11 & 3.11 & 3.11 & 21.96 & 21.96 & 21.96 \\
\hline$j 6$ & 1 & 6.01 & 6.01 & 6.01 & 27.59 & 27.59 & 27.59 \\
\hline$j 7$ & 6 & 2.30 & 0.96 & 5.65 & 20.37 & 14.71 & 33.00 \\
\hline$j 8$ & 1 & 2.66 & 2.66 & 2.66 & 20.38 & 20.38 & 20.38 \\
\hline$j 9$ & 1 & 0.87 & 0.87 & 0.87 & 16.02 & 16.02 & 16.02 \\
\hline$j 10$ & 7 & 5.11 & 2.83 & 7.50 & 27.94 & 23.59 & 31.96 \\
\hline$j 11$ & 5 & 2.61 & 1.05 & 3.65 & 18.93 & 13.68 & 25.52 \\
\hline
\end{tabular}

ANNEX 6. JARS' ESSENTIAL DIMENSIONS, CONTINUATION

double handled jars (jd class), figures from scaled images, $\mathrm{cm}$

\begin{tabular}{ccccc}
\hline js class & height & rim diameter & middle diam. & base diameter \\
\hline averages & 14.6 & 11.9 & 15.5 & 6.2 \\
\hline minimum & 11.7 & 10.0 & 12.4 & 4.8 \\
\hline maximum & 20.0 & 14.3 & 18.6 & 8.0 \\
\hline
\end{tabular}

ANNEX 6. JARS' ESSENTIAL DIMENSIONS, CONTINUATION

double handled jars (jd class), figures from scaled images, $\mathrm{cm}$

\begin{tabular}{|c|c|c|c|c|c|c|c|c|c|c|c|c|c|}
\hline \multirow{2}{*}{ Type } & \multirow{2}{*}{ Count } & \multicolumn{3}{|c|}{ height } & \multicolumn{3}{|c|}{$\operatorname{rim} \mathrm{D}}$. & \multicolumn{3}{|c|}{ middle D. } & \multicolumn{3}{|c|}{ base $D$. } \\
\hline & & aver. & $\min$. & $\max$. & aver. & min. & max. & aver. & $\min$. & max. & aver. & $\min$. & max. \\
\hline jd1 & 12 & 16.4 & 12.6 & 22.7 & 12.3 & 9.5 & 17.9 & 16.0 & 12.1 & 21.6 & 6.7 & 5.0 & 9.3 \\
\hline jd2 & 4 & 14.7 & 12.3 & 21.6 & 19.8 & 17.9 & 21.1 & 17.3 & 16.4 & 23.7 & 7.2 & 6.6 & 9.0 \\
\hline jd3 & 2 & 19.8 & 13.0 & 21.6 & 15.4 & 12.0 & 16.0 & 21.0 & 12.6 & 23.7 & 8.1 & 7.2 & 9.0 \\
\hline jd4 & 8 & 18.1 & 13.0 & 22.0 & 16.4 & 12.0 & 19.2 & 18.7 & 12.6 & 21.4 & 7.3 & 5.6 & 8.4 \\
\hline
\end{tabular}


ANNEX 7. BEAKERS AND FLAGONS

Types and fabrication on rows, colours on columns See Annex 1, fabrication and colours

\begin{tabular}{|c|c|c|c|c|c|c|c|c|c|c|c|c|c|c|c|}
\hline type & fabr. & mG & $\begin{array}{c}\text { mG\& } \\
\text { CZ }\end{array}$ & $\mathbf{m B}$ & bR & $\begin{array}{c}\text { bR\& } \\
\text { mB }\end{array}$ & bR\& $R$ & $\begin{array}{c}\text { IR\& } \\
\text { R }\end{array}$ & $d R$ & $\begin{array}{c}\mathrm{dR} \& \\
\mathrm{mB}\end{array}$ & $\begin{array}{c}\mathrm{dR} \& \\
\mathrm{R}\end{array}$ & $\begin{array}{c}\mathrm{dR} \& \\
0\end{array}$ & $\mathbf{R}$ & $\begin{array}{l}R \& \\
\text { mB }\end{array}$ & $\begin{array}{c}\text { R\& } \\
\text { R }\end{array}$ \\
\hline b1 & $\mathrm{F}$ & 2 & & & & & & & & & & & & & \\
\hline b2 & $\mathrm{Fd}$ & 1 & & & & & & & & & & & & & \\
\hline b3 & $\mathrm{F}$ & & & & & & & & 1 & & & & & & \\
\hline b3a & $\mathrm{F}$ & & & & & & & & & & & 1 & & & \\
\hline b3b & $\mathrm{F}$ & & & & & & & & 1 & & 1 & & & & \\
\hline b4 & $\mathrm{F}$ & 1 & & & & & & & & & & & & & \\
\hline f1_1 & $\mathrm{F}$ & & & & 4 & & 1 & 1 & 1 & & 7 & & 1 & & \\
\hline f1_1 & $\mathrm{Fm}$ & & & & & & & & & & 1 & & & & \\
\hline f1_2 & $\mathrm{F}$ & & & & & 1 & & & 1 & 1 & 17 & & 2 & & \\
\hline $\mathrm{f} 1 \_2 \mathrm{~b}$ & $\mathrm{~F}$ & & & & & & & & & & 3 & & & & 1 \\
\hline f1_2c & $\mathrm{F}$ & & 1 & & & & & & & & 2 & & & & \\
\hline f1_3 & $\mathrm{F}$ & & & 1 & & & & & & & 1 & & 1 & & 1 \\
\hline f1_4 & $\mathrm{F}$ & & & & & & & & 2 & & 1 & & & & \\
\hline f1_4 & $\mathrm{Fm}$ & & & & & & & & 1 & & & & & & \\
\hline f1_4v & $\mathrm{F}$ & 1 & & & & & & & & & & & & & \\
\hline f1_5 & $\mathrm{F}$ & & & & & & 1 & & 1 & 1 & 13 & & & 1 & 2 \\
\hline $\mathrm{f} 1 \_6$ & $\mathrm{~F}$ & & & & & & & & & 2 & & & & & \\
\hline f1_7 & $\mathrm{F}$ & & & & 3 & & & & 1 & 1 & 3 & & 7 & 1 & 8 \\
\hline f1_8 & $\mathrm{F}$ & & & & & & & & & & & & 1 & & \\
\hline f1_9 & $\mathrm{F}$ & & & & & & & & 3 & & & & & & \\
\hline f1_10 & $\mathrm{F}$ & & & & & & & & & & 2 & & & & \\
\hline f1_11 & $\mathrm{F}$ & & & & & & & & & & 2 & & & & \\
\hline $\mathrm{f} 1 \_12 \mathrm{a}$ & $\mathrm{F}$ & & & & & & & & & & 1 & & & & \\
\hline $\mathrm{f} 1 \_12 \mathrm{~b}$ & $\mathrm{~F}$ & & & & & & & & & & 1 & & & & \\
\hline f1_12c & $\mathrm{F}$ & & & & & & & & & & 2 & & & & \\
\hline $\mathrm{f} 1 \_12 \mathrm{c}$ & Fsd & 1 & & & & & & & & & & & & & \\
\hline $\mathrm{f} 1 \_12 \mathrm{~d}$ & $\mathrm{~F}$ & & 1 & & & & & & & & & & & & \\
\hline $\mathrm{f} 1 \_12 \mathrm{f}$ & Fsd & 1 & & & & & & & & & & & & & \\
\hline f2_1 & $\mathrm{Cr}$ & & & & & & & & & & 1 & & & & \\
\hline f2_2 & $\mathrm{F}$ & & & & & & & & & & 10 & & & & 3 \\
\hline f2_3 & $\mathrm{F}$ & & & & & & & & 1 & & & & & & \\
\hline f2_4 & $\mathrm{F}$ & & & & & & & & & & 2 & & & & \\
\hline f2_5 & $\mathrm{F}$ & & & & & & & & 5 & & & & 1 & & \\
\hline f2_6a & $\mathrm{F}$ & & & & & & & & & & & & 1 & & \\
\hline f2_6b & $\mathrm{F}$ & & & & & & & & 2 & & & & 1 & & \\
\hline
\end{tabular}


ANNEX 7 (CONTINUATION). BEAKERS AND FLAGONS. RIM CONFIGURATIONS

See Annex 1, rim morphology (columns)

\begin{tabular}{|c|c|c|c|c|c|c|c|c|c|c|c|c|c|c|c|}
\hline type & $\_211$ & $\_212$ & _213 & $\_220$ & $\_221$ & _222 & _232 & -300 & ${ }_{-311}$ & _312 & _313 & _321 & _322 & _331 & $x$ \\
\hline b1 & & & & & 1 & & & & & & & 1 & & & \\
\hline b2 & & & & & & & & & & & & 1 & & & \\
\hline b3 & & & & & & & & & & & & & 1 & & \\
\hline b3a & & 1 & & & & & & & & & & & & & \\
\hline b3b & & & & & & & & & & & & 1 & & 1 & \\
\hline b4 & & & & & & & & & & & & 1 & & & \\
\hline f1_1 & & 2 & & & & & & & 11 & 1 & & & & & 2 \\
\hline $\mathrm{f} 1 \_2$ & & 5 & & & 14 & 1 & & & & & & & & & 2 \\
\hline $\mathrm{f} 1 \_2 \mathrm{~b}$ & & & & & 2 & 2 & & & & & & & & & \\
\hline $\mathrm{f} 1 \_2 \mathrm{c}$ & & & & & & 3 & & & & & & & & & \\
\hline f1_3 & & & & & & 4 & & & & & & & & & \\
\hline f1_4 & & & & & 4 & & & & & & & & & & \\
\hline f1_4v & & & & & 1 & & & & & & & & & & \\
\hline f1_5 & & & 2 & & & & & & & 9 & 8 & & & & \\
\hline $\mathrm{f} 1 \_6$ & & & 2 & & & & & & & & & & & & \\
\hline f1_7 & & 4 & 19 & & & 1 & & & & & & & & & \\
\hline f1_8 & & & & & & & & 1 & & & & & & & \\
\hline f1_9 & 2 & 1 & & & & & & & & & & & & & \\
\hline $\mathrm{f} 1 \_10$ & & & & & & 2 & & & & & & & & & \\
\hline f1_11 & & & & & 2 & & & & & & & & & & \\
\hline f1_12a & & & & & & & & & & & & & 1 & & \\
\hline $\mathrm{f} 1 \_12 \mathrm{~b}$ & & & & & & & & & & & & & 1 & & \\
\hline $\mathrm{f} 1 \_12 \mathrm{c}$ & & & & & & & 2 & & & & & & 1 & & \\
\hline $\mathrm{f} 1 \_12 \mathrm{~d}$ & & & & & & & & & & & & & 1 & & \\
\hline $\mathrm{f} 1 \_12 \mathrm{f}$ & & & & & & & & & & & & & 1 & & \\
\hline f2_1 & & 1 & & & & & & & & & & & & & \\
\hline f2_2 & & & & 13 & & & & & & & & & & & \\
\hline f2_3 & & & & & 1 & & & & & & & & & & \\
\hline f2_4 & & & & & 2 & & & & & & & & & & \\
\hline f2_5 & & & & & 6 & & & & & & & & & & \\
\hline f2_6a & & & & & 1 & & & & & & & & & & \\
\hline f2_6b & & & & & 3 & & & & & & & & & & \\
\hline
\end{tabular}


ANNEX 7 (CONTINUATION). LIP CONFIGURATION

See Annex 1, lip morphology (columns)

\begin{tabular}{|c|c|c|c|c|c|c|c|c|c|c|c|}
\hline type & A & B & $\mathbf{F}$ & F- & $\mathbf{F +}$ & $\mathbf{R}$ & $\mathbf{S}$ & $\mathbf{T}$ & T2 & $\mathbf{Y}$ & $x$ \\
\hline b1 & & & & & & 1 & 1 & & & & \\
\hline b2 & & & & & & & & & & & 1 \\
\hline b3 & & & & & & & 1 & & & & \\
\hline b3a & & & & & & 1 & & & & & \\
\hline b3b & & & & & & 2 & & & & & \\
\hline b4 & & & & & & 1 & & & & & \\
\hline f1_1 & & & & & & 8 & 2 & 4 & & & 2 \\
\hline f1_2 & & & & & & 2 & 17 & & & & 3 \\
\hline $\mathrm{f} 1 \_2 \mathrm{~b}$ & & & & & & 1 & 3 & & & & \\
\hline f1_2c & & & & & & & 3 & & & & \\
\hline f1_3 & & & & 2 & 2 & & & & & & \\
\hline f1_4 & & & & & & & & & & 3 & 1 \\
\hline $\mathrm{f} 1 \_4 \mathrm{v}$ & & & & & & & & & & 1 & \\
\hline f1_5 & & & 8 & & 11 & & & & & & \\
\hline $\mathrm{f} 1 \_6$ & & & & & 2 & & & & & & \\
\hline f1_7 & & & & & 22 & & & 2 & & & \\
\hline $\mathrm{f} 1 \_8$ & & & & & & 1 & & & & & \\
\hline f1_9 & & & & & 3 & & & & & & \\
\hline f1_10 & & & & & & 2 & & & & & \\
\hline f1_11 & & & & & & & & & 2 & & \\
\hline f1_12a & & 1 & & & & & & & & & \\
\hline $\mathrm{f} 1 \_12 \mathrm{~b}$ & & 1 & & & & & & & & & \\
\hline $\mathrm{f} 1 \_12 \mathrm{c}$ & & 3 & & & & & & & & & \\
\hline $\mathrm{f} 1 \_12 \mathrm{~d}$ & & 1 & & & & & & & & & \\
\hline $\mathrm{f} 1 \_12 \mathrm{f}$ & & 1 & & & & & & & & & \\
\hline f2__1 & & & & & & 1 & & & & & \\
\hline f2_2 & 13 & & & & & & & & & & \\
\hline f2_3 & & & & & & & 1 & & & & \\
\hline f2_ 4 & & & & & & 1 & & 1 & & & \\
\hline f2_5 & & & & & & 4 & 2 & & & & \\
\hline f2_6a & & & & & & & & & 1 & & \\
\hline$f 2 \_6 b$ & & & & & & & & & 3 & & \\
\hline
\end{tabular}




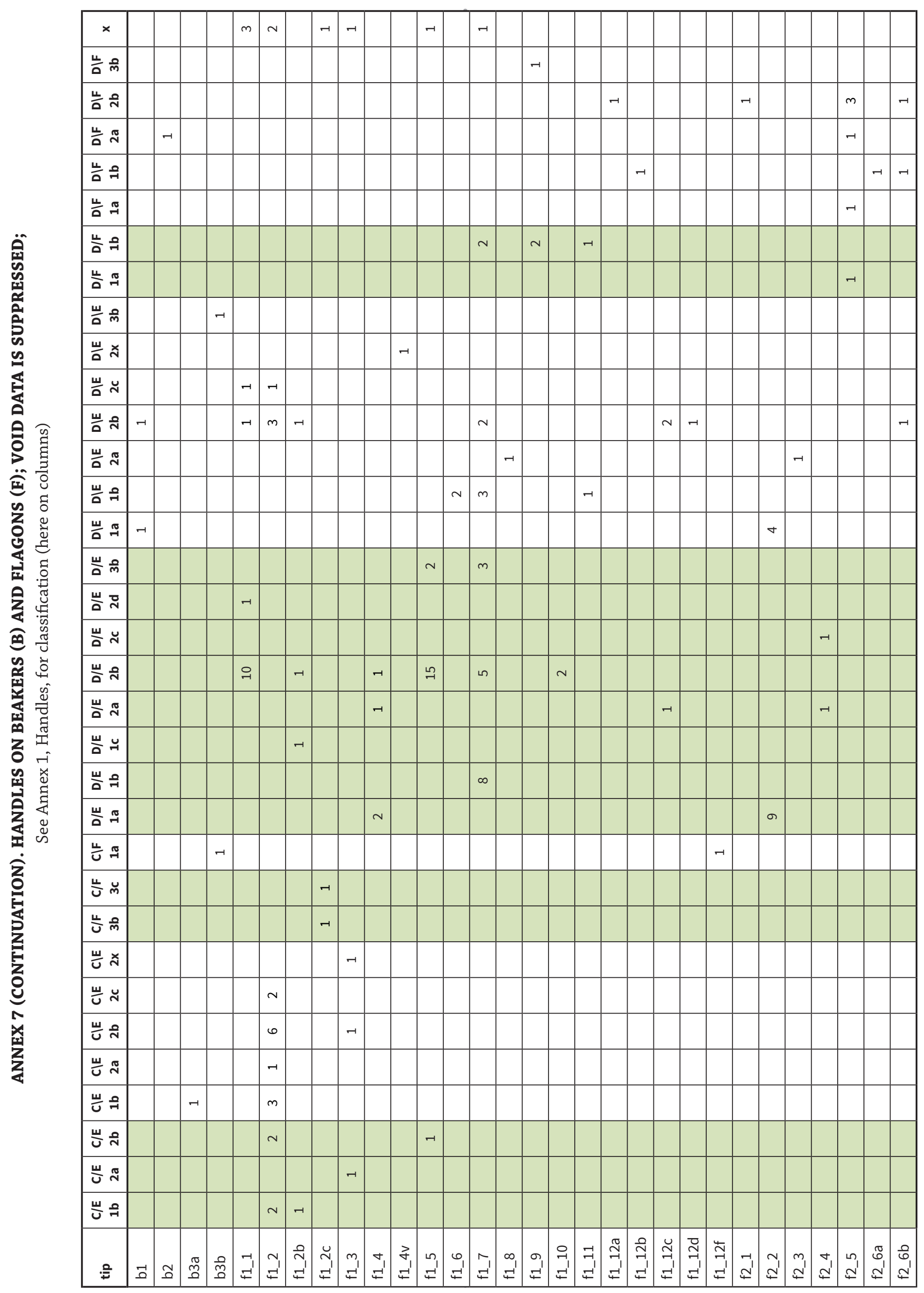


ANNEX 7 (CONTINUATION). BEAKERS (B) AND FLAGONS (F). BASE CONFIGURATIONS (COLUMNS).

See Annex 1, Annex 1, base morphology

\begin{tabular}{|l|l|l|l|l|l|l|l|l|l|l|l|}
\hline type & 1a & 1b & 2a & 2b & 2c & 2e & 3a & 3b & 3c & 3e & x \\
\hline b1 & & & & & & & & & 2 & & \\
\hline b2 & & & & & & & & & 1 & & \\
\hline b3 & & & & & & & & & & & 1 \\
\hline b3a & & & & & & & 1 & & & & \\
\hline b3b & & & & & & & 1 & & 1 & & \\
\hline b4 & & & & 1 & & & & & & & \\
\hline f1_1 & & & 1 & & 1 & & & & 11 & 2 & 1 \\
\hline f1_2 & & & & & & & & & 22 & & \\
\hline f1_2b & & & & & & & & 4 & & & \\
\hline f1_2c & & & & 1 & & 1 & & & 1 & & \\
\hline f1_3 & & & & & 1 & & & & 2 & 1 & \\
\hline f1_4 & & & & 1 & & & & & 2 & 1 & \\
\hline f1_4v & & & & & & & & & 1 & & \\
\hline f1_5 & & & 1 & & & 3 & & & 9 & 6 & \\
\hline f1_6 & & & & & & 2 & & & & & \\
\hline f1_7 & & & & & & & 1 & 4 & 5 & 14 & \\
\hline f1_8 & & & & & & & & & & 1 & \\
\hline f1_9 & & & 2 & & & & & & & 1 & \\
\hline f1_10 & & & & & & & & & & 2 & \\
\hline f1_11 & & & & & & & & & & 2 & \\
\hline f1_12a & & & & & & & & & 1 & & \\
\hline f1_12b & & & & & & & & & 1 & & \\
\hline f1_12c & & & 1 & 2 & & & & & & & \\
\hline f1_12d & 1 & & & & & & & & & & \\
\hline f1_12f & & 1 & & & & & & & & & \\
\hline f2_1 & 1 & & & & & & & & & & \\
\hline f2_2 & & & & & & & & & 10 & 3 & \\
\hline f2_3 & & & 1 & & & & & & & & \\
\hline f2_4 & & & & & & & & & & 2 & \\
\hline f2_5 & & & & & & & & 1 & 3 & 2 & \\
\hline f2_6a & & & & & & & & & 1 & & \\
\hline f2_6b & & & & & & & & & 3 & & \\
\hline
\end{tabular}

where $\mathrm{b}=$ beaker, $\mathrm{f} 1_{-}=\mathrm{a}$ single handled flagon, $\mathrm{f} 2_{-}=\mathrm{a}$ double handled flagon
ANNEX 7 (CONTINUATION). DECORATION ON BEAKERS (B) AND FLAGONS (F)

See Annex 1, Annex 1, , decoration

\begin{tabular}{|c|c|c|c|c|c|}
\hline type & e & $\mathbf{n}$ & rd & g & gg \\
\hline b1 & & & 1 & & 1 \\
\hline b2 & & & 1 & & \\
\hline b3 & & & & & 1 \\
\hline b3a & & 1 & & & \\
\hline b3b & & & & 2 & \\
\hline b4 & & 1 & & & \\
\hline f1_1 & & 15 & & 1 & \\
\hline f1_2 & & 8 & & 14 & \\
\hline $\mathrm{f} 1 \_2 \mathrm{~b}$ & & 1 & & 3 & \\
\hline f1_2c & & 2 & & 1 & \\
\hline f1_3 & & 3 & & 1 & \\
\hline f1_4 & 1 & 3 & & & \\
\hline f1_4v & & 1 & & & \\
\hline f1_5 & 1 & 17 & 1 & & \\
\hline f1_6 & & 2 & & & \\
\hline$f 1 \_7$ & & 24 & & & \\
\hline f1_8 & & 1 & & & \\
\hline f1_9 & & 3 & & & \\
\hline $\mathrm{f} 1 \_10$ & & 2 & & & \\
\hline f1_11 & & 1 & & 1 & \\
\hline f1_12a & & 1 & & & \\
\hline $\mathrm{f} 1 \_12 \mathrm{~b}$ & & 1 & & & \\
\hline $\mathrm{f} 1 \_12 \mathrm{c}$ & & 2 & & & 1 \\
\hline f1_12d & & & & & 1 \\
\hline f1_12f & & & & 1 & \\
\hline f2_1 & & & & & 1 \\
\hline$f 2 \_2$ & & 13 & & & \\
\hline f2_3 & & & & & 1 \\
\hline f2_4 & & 2 & & & \\
\hline f2_5 & & 6 & & & \\
\hline f2_6a & & 1 & & & \\
\hline f2_6b & & 3 & & & \\
\hline
\end{tabular}

OVERVIEW

\begin{tabular}{|l|c|c|c|c|c|}
\hline type & e & $\mathbf{n}$ & rd & g & gg \\
\hline b & 0 & 2 & 2 & 1 & 2 \\
\hline f1 & 2 & 17 & 1 & 7 & 2 \\
\hline f2 & 0 & 5 & 0 & 0 & 2 \\
\hline all & 2 & 24 & 3 & 8 & 6 \\
\hline
\end{tabular}




\section{ANNEX 8. OPEN SHAPES}

Deep bowls (db), shallow bowls ( $\mathrm{b} b)$, dishes (ds), plattes (p)

Colour and fabric (see Annex 1 for codification)

\begin{tabular}{|c|c|c|c|c|c|c|}
\hline type & colour & $\mathrm{X}$ & $\mathbf{F}$ & Fsd & Fd & $\mathrm{Cr}$ \\
\hline db1a & $\mathrm{mG} \& \mathrm{dG}$ & & 1 & & & \\
\hline $\mathrm{db} 1 \mathrm{a}$ & IR\&R & 1 & 1 & & & \\
\hline dbla & $d R \& R$ & & 2 & & & \\
\hline $\mathrm{db} 1 \mathrm{~b}$ & $\mathrm{dR}$ & & 2 & & 1 & \\
\hline $\mathrm{db} 1 \mathrm{c}$ & $\mathrm{mG}$ & & & & 1 & \\
\hline $\mathrm{db} 1 \mathrm{c}$ & $\mathrm{dR}$ & & 1 & & & \\
\hline $\mathrm{db} 1 \mathrm{c}$ & $d R \& R$ & & 1 & & & \\
\hline $\mathrm{db} 2$ & $d R \& R$ & & 3 & & & \\
\hline $\mathrm{db} 2$ & $\mathrm{dR} \& \mathrm{X}$ & & 1 & & & \\
\hline db3 & IR\&dB & & 1 & & & \\
\hline db3 & $\mathrm{dR} \& \mathrm{~dB}$ & & & & 1 & \\
\hline $\mathrm{db} 4$ & $\mathrm{dR}$ & & 2 & & & \\
\hline db5 & $\mathrm{mB}$ & & & & & 1 \\
\hline db5 & $\mathrm{dG}$ & & & & & 11 \\
\hline db5 & IR & & & & & 1 \\
\hline db5 & $\mathrm{dR}$ & & & & & 1 \\
\hline $\mathrm{db} 6$ & $\mathrm{dR}$ & & 4 & & & \\
\hline $\mathrm{db} 6$ & $d R \& I R$ & & 1 & & & \\
\hline $\mathrm{db} 6$ & $\mathrm{dR} \& \mathrm{X}$ & & 1 & & & \\
\hline $\mathrm{db} 7$ & $\mathrm{dR}$ & & 5 & & & \\
\hline $\mathrm{db} 7$ & $\mathrm{dR} \& \mathrm{X}$ & & 1 & & & \\
\hline sb1 & IR\&R & & 1 & & & \\
\hline sb1 & $\mathrm{dR}$ & & 5 & & & \\
\hline sb1 & $d R \& R$ & & 1 & & & \\
\hline $\mathrm{sb} 2$ & $d R$ & & 7 & & & \\
\hline $\mathrm{sb} 2$ & $d R \& R$ & & 1 & & & \\
\hline sb3 & $\mathrm{dR}$ & & 7 & & & \\
\hline sb3 & $d R \& R$ & & 2 & & & \\
\hline
\end{tabular}

\begin{tabular}{|c|c|c|c|c|c|c|}
\hline type & colour & $\mathbf{x}$ & $\mathbf{F}$ & Fsd & $\mathbf{F d}$ & $\mathrm{Cr}$ \\
\hline ds1 & $\mathrm{mG}$ & & & & & 6 \\
\hline ds1 & $d R$ & & & & & 1 \\
\hline ds2 & IR & & 2 & & & \\
\hline ds2 & $\mathrm{dR}$ & & 2 & 1 & & \\
\hline ds3 & W & 5 & & & & \\
\hline ds4 & $m G$ & & & & & 2 \\
\hline ds5 & W & 1 & & & & \\
\hline ds5 & $m G$ & & & & & 6 \\
\hline ds5 & $d R$ & & & & & 1 \\
\hline ds 6 & $\mathrm{RC} \& \mathrm{R}$ & & 2 & & & \\
\hline ds 6 & $\mathrm{dR}$ & & 2 & & & \\
\hline ds6 & $\mathrm{dR} \& \mathrm{R}$ & & 7 & & & \\
\hline ds7 & $\mathrm{mG}$ & & 1 & & & \\
\hline ds7 & $m G \& d G$ & & 1 & & & \\
\hline ds7 & IR & & 1 & & & \\
\hline ds7 & $\mathrm{dR}$ & & 5 & & 1 & \\
\hline ds7 & $d R \& \mid R$ & & 1 & & & \\
\hline ds7 & $\mathrm{dR} \& \mathrm{R}$ & & 1 & & 1 & \\
\hline ds7 & $R \& R$ & & 1 & & & \\
\hline $\mathrm{p} 1$ & $m G$ & & 1 & & & \\
\hline $\mathrm{p} 1$ & $\mathrm{dR}$ & & 2 & & & \\
\hline $\mathrm{p} 1$ & $\mathrm{dR} \& \mathrm{R}$ & & 2 & & & \\
\hline p2 & IR\&IR & & 1 & & & \\
\hline p2 & $\mathrm{dR}$ & & 2 & & & \\
\hline p2 & $\mathrm{dR} \& \mid \mathrm{R}$ & & 1 & & & \\
\hline p2 & $\mathrm{dR} \& \mathrm{R}$ & & 2 & & & \\
\hline p2 & $\mathrm{dR} \& \mathrm{X}$ & & 3 & & & \\
\hline p3 & IR\&mB & & & & 1 & \\
\hline
\end{tabular}

ANNEX 8. OPEN SHAPES (CONTINUATION)

Lip and rim configurations

\begin{tabular}{|c|c|c|c|c|c|c|c|c|c|c|c|c|c|}
\hline type & lip & _000 & _111 & _112 & _113 & _121 & _122 & _123 & _133 & _212 & _222 & _223 & _233 \\
\hline db1a & $\mathrm{T}$ & & 3 & 1 & & & & & & & & & \\
\hline $\mathrm{db} 1 \mathrm{a}$ & $\mathrm{F}$ & & & & 1 & & & & & & & & \\
\hline $\mathrm{db} 1 \mathrm{~b}$ & $\mathrm{R}$ & & 3 & & & & & & & & & & \\
\hline $\mathrm{db} 1 \mathrm{c}$ & $S$ & & & 1 & & & & & & & & & \\
\hline $\mathrm{db} 1 \mathrm{c}$ & $\mathrm{R}$ & & 2 & & & & & & & & & & \\
\hline $\mathrm{db} 2$ & $\mathrm{R}$ & 1 & 3 & & & & & & & & & & \\
\hline db3 & $S$ & 1 & & & & & & & & & & & \\
\hline db3 & $\mathrm{R}$ & & & 1 & & & & & & & & & \\
\hline $\mathrm{db} 4$ & $\mathrm{R}$ & 2 & & & & & & & & & & & \\
\hline db5 & $S$ & & & & & & & & & & 1 & & \\
\hline
\end{tabular}




\begin{tabular}{|c|c|c|c|c|c|c|c|c|c|c|c|c|c|}
\hline type & lip & _000 & _111 & _112 & _113 & _121 & _122 & _123 & _133 & -212 & $ـ_{222}$ & ${ }_{-223}$ & _233 \\
\hline $\mathrm{db} 5$ & $\mathrm{~F}$ & & & & 1 & & & & & & 1 & 1 & \\
\hline db5 & $\mathrm{R}$ & & & & 1 & & 1 & & & & 8 & & \\
\hline $\mathrm{db} 6$ & $\mathrm{R}$ & 2 & 4 & & & & & & & & & & \\
\hline $\mathrm{db} 7$ & $\mathrm{R}$ & & 5 & & & & 1 & & & & & & \\
\hline $\mathrm{sb} 1$ & $\mathrm{~T}$ & & & & & 1 & & & & & & & \\
\hline sb1 & $\mathrm{R}$ & 5 & 1 & & & & & & & & & & \\
\hline sb2 & $S$ & & & & & & 1 & & & & & & \\
\hline sb2 & $\mathrm{R}$ & & & 4 & & & 1 & 1 & & & 1 & & \\
\hline sb3 & $\mathrm{T}$ & & 1 & 1 & & & & & & & & & \\
\hline sb3 & $\mathrm{R}$ & 1 & 4 & 1 & & 1 & & & & & & & \\
\hline ds1 & $\mathrm{F}-$ & & & & & 7 & & & & & & & \\
\hline $\mathrm{ds} 2$ & $\mathrm{~F}+$ & & 5 & & & & & & & & & & \\
\hline ds3 & $\mathrm{F}+$ & & & & & & & & 5 & & & & \\
\hline ds4 & $\mathrm{R}-$ & 2 & & & & & & & & & & & \\
\hline ds5 & $\mathrm{T}-$ & 4 & & & & & & & & & & & \\
\hline ds5 & $\mathrm{R}$ & 1 & & & & & & & & & & & \\
\hline ds5 & $\mathrm{R}-$ & 3 & & & & & & & & & & & \\
\hline ds6 & $\mathrm{R}$ & & & & & & & & & 6 & & 5 & \\
\hline ds7 & $\mathrm{R}$ & & & & & & & & & 3 & & 9 & 1 \\
\hline $\mathrm{p} 1$ & $\mathrm{R}$ & 5 & & & & & & & & & & & \\
\hline p2 & $\mathrm{R}$ & 2 & & & & & & & & & & & \\
\hline p2 & $\mathrm{R}-$ & 7 & & & & & & & & & & & \\
\hline p3 & $\mathrm{R}-$ & 1 & & & & & & & & & & & \\
\hline
\end{tabular}

ANNEX 8. OPEN SHAPES (CONTINUATION)

Base configuration

\begin{tabular}{|c|c|c|c|c|c|c|c|c|c|c|}
\hline type & 1a & $1 \mathrm{~b}$ & $1 c$ & $2 a$ & $2 b$ & $2 c$ & 3- & $3 a$ & $3 b$ & $3 c$ \\
\hline db1a & & & & & & 3 & & & & 2 \\
\hline$d b 1 b$ & & & & 1 & & & & & & 2 \\
\hline db1c & & & & & 1 & & & & & 2 \\
\hline $\mathrm{db} 2$ & & & & & & 1 & & 1 & & 2 \\
\hline db3 & & & & & & 1 & & & & 1 \\
\hline $\mathrm{db} 4$ & & & & 1 & & 1 & & & & \\
\hline $\mathrm{db} 5$ & 8 & & & 2 & 3 & & & 1 & & \\
\hline $\mathrm{db} 6$ & & & & & & & & & & 6 \\
\hline $\mathrm{db} 7$ & & & & & & & & & & 6 \\
\hline sb1 & & & & 3 & 1 & & & & & 3 \\
\hline $\mathrm{sb} 2$ & & & & 1 & & 1 & & & & 6 \\
\hline sb3 & & & & 2 & & & & & 1 & 6 \\
\hline ds1 & 6 & 1 & & & & & & & & \\
\hline $\mathrm{ds} 2$ & 5 & & & & & & & & & \\
\hline $\mathrm{d} s 3$ & 5 & & & & & & & & & \\
\hline $\mathrm{ds} 4$ & 2 & & & & & & & & & \\
\hline ds5 & 4 & & & 1 & 3 & & & & & \\
\hline $\mathrm{ds} 6$ & & & & & & & & & & 11 \\
\hline ds7 & & & & & & & & & & 13 \\
\hline
\end{tabular}




\begin{tabular}{|c|c|c|c|c|c|c|c|c|c|c|}
\hline type & $1 a$ & 1b & $1 c$ & $2 a$ & $2 b$ & $2 c$ & 3- & $3 a$ & $3 b$ & $3 c$ \\
\hline $\mathrm{p} 1$ & & & & & & & 3 & & & 2 \\
\hline p2 & 8 & & 1 & & & & & & & \\
\hline p3 & & & & & & & 1 & & & \\
\hline
\end{tabular}

ANNEX 8. OPEN SHAPES (CONTINUATION)

Decoration

\begin{tabular}{|c|c|c|c|c|c|c|c|c|c|c|}
\hline type & e & e_rb & $\mathbf{n}$ & p? & rb & g_rb & $\mathbf{t}$ & c_g & g & gg \\
\hline $\mathrm{db} 1 \mathrm{a}$ & & & & & 3 & 2 & & & & \\
\hline $\mathrm{db} 1 \mathrm{~b}$ & & & & & 1 & 1 & & & 1 & \\
\hline $\mathrm{db} 1 \mathrm{c}$ & & & & & 3 & & & & & \\
\hline $\mathrm{db} 2$ & & & 2 & 1 & & & & & 1 & \\
\hline db3 & & 1 & & & & 1 & & & & \\
\hline $\mathrm{db} 4$ & 2 & & & & & & & & & \\
\hline db5 & & & 4 & & & & & & 9 & 1 \\
\hline db6 & & & & & & & & 1 & 5 & \\
\hline $\mathrm{db} 7$ & & & 3 & & & & & & 3 & \\
\hline sb1 & & & 6 & & & & & & 1 & \\
\hline sb2 & & & 6 & & & & & & & 2 \\
\hline sb3 & & & 2 & & & & 1 & & 4 & 2 \\
\hline ds1 & & & 4 & & & & & & 3 & \\
\hline ds2 & & & 1 & & & & & & 4 & \\
\hline ds3 & & & & & & & & & 5 & \\
\hline ds4 & & & 2 & & & & & & & \\
\hline ds5 & 1 & & 7 & & & & & & & \\
\hline ds6 & & & 11 & & & & & & & \\
\hline ds7 & & & 12 & & & & & & 1 & \\
\hline $\mathrm{p} 1$ & & & 5 & & & & & & & \\
\hline p2 & & & 9 & & & & & & & \\
\hline p3 & & & 1 & & & & & & & \\
\hline
\end{tabular}

